\title{
What Affects Innovation More: Policy or Policy Uncertainty?
}

\author{
Utpal Bhattacharya, Po-Hsuan Hsu, Xuan Tian, and Yan Xu*
}

\begin{abstract}
Motivated by a theoretical model, we examine for 43 countries whether it is policy or policy uncertainty that affects technological innovation more. Innovation activities, measured by patent-based proxies, are not, on average, affected by which policy is in place. Innovation activities, however, drop significantly during times of policy uncertainty measured by national elections. The drop is greater for more influential innovations (citations in the right tail, exploratory rather than exploitative innovations) and for innovation-intensive industries. We use close presidential elections and ethnic fractionalization to address endogeneity concerns. We uncover the mechanism underlying the main result by showing that the number of patenting inventors decreases with policy uncertainty. Political compromise, we conclude, encourages innovation.
\end{abstract}

\section{Introduction}

The important role of technological innovation in promoting a nation's longterm economic growth and competitive advantage has been established since the

*Bhattacharya, ubhattac@ust.hk, Business School, Hong Kong University of Science and Technology; Hsu, paulhsu@hku.hk, Xu (corresponding author), yanxuj@hku.hk, Faculty of Business and Economics, University of Hong Kong; and Tian, tianx@ pbcsf.tsinghua.edu.cn, PBC School of Finance, Tsinghua University. We are grateful for helpful comments from Tim Adam, Geert Bekaert, Jonathan Brogaard, Yenn-Ru Chen, Cyrus Chu, Art Durnev, Jarrad Harford (the editor), Harald Hau, Erik Hurst, Kanhon Kan, Andrew Karolyi, Margaret Kyle, Rafael La Porta, Florencio Lopez-de-Silanes, Gustavo Manso, Ronald Masulis, Lubos Pastor, Gordon Phillips, Andrea Prat, Rene Stulz, Krishnamurthy Subramanian (the referee), Han Xia, Zhaoxia Xu, Youngsuk Yook, Alminas Zaldokas, and seminar and conference participants at Academia Sinica, Indiana University, National Taiwan University, University of Hong Kong, the 2015 Financial Management Association Asian Meeting, the 2015 Taiwan Finance Association Annual Meeting, the 2014 China International Conference in Finance, and the 2014 European Finance Association Conference. We thank Jiyao Fan, Michael Flores, Xiaowen Jin, Amit Kumar, Yunan Liu, Nikhil Singh, and Tong Zhou for their research assistance. Hsu and Xu acknowledge the support from the General Research Fund sponsored by the Research Grants Council in Hong Kong (Refs. 17500015 and 17502514). Tian acknowledges financial support from Tsinghua University Research Grant (Project No. 20151080451). We remain responsible for any remaining errors or omissions. 
seminal work of Solow (1957). ${ }^{1}$ Although a growing literature has examined various empirical links between innovation and firm- or market-specific characteristics, rigorous empirical studies that explore how politics affects innovation activities are sparse. Politics is important to innovation because politicians make policy and regulatory decisions that frequently alter the economic environment in which innovative firms operate, which ultimately affects a nation's innovation progress. For example, in the 2013 edition of the Global Innovation Index (GII) (Dutta and Lanvin (2013)) that serves as a comprehensive measure of innovation in an economy, the first two indicators are political stability and government effectiveness under the political environment category. ${ }^{2}$ In this article, we contribute to this nascent literature by examining the real effects of politics on innovation activities. Specifically, we study whether innovation is more affected by policy or by policy uncertainty.

Innovation is a special investment in long-term, intangible assets that will generate profits in the future. It is different from regular investment in tangible assets such as capital expenditures because of its longer investment time horizon and higher tail risk. Moreover, economic factors affecting innovation are also different from those that affect regular investment. ${ }^{3}$ Hence, although existing studies show that policy uncertainty adversely affects investment in tangible assets (e.g., Alesina and Perotti (1996), Bloom, Bond, and Van Reenen (2007), Julio and Yook (2012), and Gulen and Ion (2016)), it is unclear how policy uncertainty affects investment in intangible assets that generates technological innovation. Furthermore, although one can measure the effect of policy uncertainty on the quantity of ordinary capital investment, one cannot easily judge its effect on the quality and originality of this investment. That said, we do not face this issue for technological innovation. In patent data, which we use to capture innovation activities, we observe both the number of patents a country generates (quantity of innovation) and the number of citations these patents receive subsequently (quality of innovation). In addition, based on the distribution of citations across technology classes, we can even calculate the originality and riskiness of these patents.

We propose two hypotheses in this article with respect to the relative importance of policy or policy uncertainty in determining technological innovation, based on the existing literature. Our first hypothesis, the "policy hypothesis," states that it is policy that affects innovation activities. If one defines policy in the left-right spectrum (as does the World Bank, from which we obtain our policy data), a right-leaning (left-leaning) government would (would not) prefer

\footnotetext{
${ }^{1}$ According to Rosenberg (2004), about $85 \%$ of economic growth is attributable to technological innovation.

${ }^{2}$ The GII is an index ranging from 0 to 100 that is developed by the World Intellectual Property Organization, a specialized agency of the United Nations.

${ }^{3}$ For instance, the initial public offering (IPO) literature shows that going public allows firms to raise equity capital to increase capital expenditures. However, Lerner, Sorensen, and Stromberg (2011) and Chen, Gao, Hsu, and $\mathrm{Li} \mathrm{(2016)} \mathrm{show} \mathrm{that} \mathrm{private} \mathrm{instead} \mathrm{of} \mathrm{public} \mathrm{ownership} \mathrm{promotes} \mathrm{innovation}$ because private ownership allows for more failure tolerance from investors. Although existing studies argue that financial analysts reduce information asymmetry and the cost of capital, which in turn increases capital expenditures (e.g., Derrien and Kecskés (2013)), Benner and Ranganathan (2012) and $\mathrm{He}$ and Tian (2013) find that analysts hinder innovation because they impose short-term pressure to meet earnings targets on managers.
} 
labor-saving innovations such as robotic technology. If one defines policy in the liberal-conservative spectrum, a conservative (liberal) government would (would not) prefer innovations in old and established industries such as oil and gas. If one defines policy in the religious spectrum, a secular (religious) government would (would not) prefer innovations in birth control. Hence, we do not assume that policies have to vary only in the left-right economic spectrum. Neither do we assume, as we use country fixed effects, that the policies of left and right are the same in all countries. In sum, our first hypothesis is simply that policies matter for innovation activities.

An alternative, though not mutually exclusive, hypothesis, referred to as the "policy uncertainty hypothesis," argues that it is policy uncertainty that adversely affects innovation. Starting from Bernanke (1983), various theoretical models (e.g., Chen and Funke (2003), Bloom et al. (2007), and Bloom, Draca, and Van Reenen (2016)) show that if investment projects are not fully reversible, firms become cautious and hold back on investment in the face of uncertainty because uncertainty increases the value of the option to wait. The value of the option to wait is particularly important for investments in research and development $(R \& D)$, given that innovation is the exploration of unknown approaches and untested methods (Holmstrom (1989), Aghion and Tirole (1994), Manso (2011), and Ferreira, Manso, and Silva (2014)) that require considerable investment in intangible assets. The value of the option to wait is even more important for innovation in an uncertain political environment because, as we discuss earlier, the value of success in innovative exploration depends on which government is in power. The following example from the United States illustrates this point. The "left" in the United States prefers to subsidize innovations in solar and wind energy, whereas the "right" in the United States prefers to subsidize innovations in fracking methods in oil and gas. An energy company, which is deciding on whether to spend its R\&D dollars on developing prototypes of either better solar cells or better fracking pumps for oil and gas, may wish to postpone this decision until after the elections. Therefore, the uncertainty hypothesis states that policy uncertainty adversely affects innovation activities.

A key question, then, emerges: Which affects innovation more, policy or policy uncertainty? To illustrate the relative importance of policy versus policy uncertainty in determining innovation, we develop a simple model based on Stein (1988) and Edmans (2009). Although insights on the effect of uncertainty and on modeling innovation are established in the literature, our theoretical model is needed because it helps us understand and develop testable implications on an issue that we introduce in our article: the horse race between policy and policy uncertainty.

Our model considers an economy in which businesses adapt to their policy environment to produce appropriate innovations, but innovations produced under one policy environment are less appropriate for a different policy environment. We obtain the following testable implication from our model: Policy uncertainty is more important than policy in countries where a political party does not dominate with respect to efficiency in promoting innovation, and vice versa. One may wonder how uncertainty in the level may matter when the level itself may not. The intuition comes from our theoretical model. In this model, during a nonelection 
year, there is no policy uncertainty. Policy is linked to productivity, and productivity of innovation $i$ under policy $I$ may be similar (very dissimilar) to productivity of innovation $j$ under policy $J$, and so the actual policy would not (would) affect innovation in a nonelection year. Policy uncertainty spikes up in an election year. Therefore, although the productivity of innovation $i$ under policy $I$ may be similar to the productivity of innovation $j$ under policy $J$, the productivity of innovation $i(j)$ under policy $J(I)$ is very low because the political parties do not encourage the opposing party's innovation policies. It may be wise, therefore, for a firm to wait until the election is over.

To empirically test this implication, we must overcome two main empirical hurdles. First, although the World Bank defines policy for researchers (left of center, center, or right of center), it is difficult to capture policy uncertainty. Moreover, although existing work has used various firm-specific proxies to capture the uncertainty faced by firms and other economic agents (these proxies include stock return volatility, dispersion in analyst forecasts, and input and output prices, as well as certain types of macroeconomic policies such as fiscal, monetary, and social security policies), these measures do not capture the overall level of policy uncertainty in the economy. To clear this hurdle, we follow Julio and Yook (2012) and use national elections (including presidential and parliamentary elections) in 43 countries to capture policy uncertainty. ${ }^{4}$ Because election outcomes are relevant to all aspects of policies (e.g., fiscal, monetary, trade, social security, industry regulation, and taxation), national elections are a reasonable proxy for overall policy uncertainty.

The second hurdle of our study is to identify the causal effect of policy or policy uncertainty on technological innovation, which is due to both omitted variables and reverse causality concerns. Certain unobservable country characteristics that affect both policy or policy uncertainty and innovation could bias our estimation and make correct statistical inferences hard to draw (the omitted variables problem). In addition, expected differences in nations' innovation intensity and innovation potential could affect their current policy as well as policy uncertainty (the reverse causality concern).

To deal with omitted variables that do not vary with time, we include countryindustry fixed effects in our regressions. This strategy implies that our research design exploits the time-series variation within country-industry units; the crosssectional variation across these units just adds power. This research design also dictates our choice of countries: We can use only 43 countries that have elections in which different parties not only can win but do win. To deal with time-varying omitted variables as well as reverse causality, we use close presidential elections. As argued by Julio and Yook (2012), presidential elections around the world provide a natural and clean experimental framework for studying how politics influences many economic decisions (in their case it is firm investments in tangible assets) because the timing of presidential elections is beyond the control of any firm and is fixed in time by constitutional rules. We move one step further and

\footnotetext{
${ }^{4}$ An alternative proxy is the political risk rating in the International Country Risk Guide database. As argued in Henisz (2000), those ratings are based on subjective opinions and are not closely linked to political institutions.
} 
focus on close presidential elections because these election results are unpredictable and reasonably exogenous.

Our second identification attempt is to rely on ethnic fractionalization, which is exogenous to most economic and political factors (see Alesina, Devleeschauwer, Easterly, and Kurlat (2003) for a discussion). Because the social disruptions caused by elections are more pronounced in a society of higher disagreement, higher distrust, and greater ethnic tension, we expect that ethnic fractionalization amplifies the adverse effect of policy and policy uncertainty on innovation activities (e.g., Connor (1994), La Porta, Lopez-de-Silanes, Shleifer, and Vishny (1999), and Radro i Miquel (2007)).

To capture innovation activities in the cross-country framework, we use observable patent variables at both country and country-industry levels. Our use of patenting as a proxy for innovation activities has become standard in the innovation literature (e.g., Acharya and Subramanian (2009), Hsu, Tian, and Xu (2014), Acharya, Baghai, and Subramanian (2013), (2014), Chava, Oettl, Subramanian, and Subramanian (2013), Sapra, Subramanian, and Subramanian (2014), and Bloom et al. (2016)). Moreover, the literature has shown that patents predict economic growth, aggregate stock market value, and firm profitability (Hsu (2009), Hirshleifer, Hsu, and Li (2013), and Kogan, Papanikolaou, Seru, and Stoffman (2017)), which supports our use of patent data to examine the real effects of policy and policy uncertainty.

We collect country-industry-level innovation data from two databases that contain detailed information about U.S. patents and their inventors. Details about these databases are discussed later. Furthermore, we look at various dimensions of innovation: quantity (patent counts), quality (citations), originality (citations to different fields), riskiness (tails and standard deviation of the citation distribution, lack of self-cites), and exploratory versus exploitative patents. In addition, we consider the annual level of total R\&D expenses reported by all publicly listed firms in the Worldscope database as a supplementary proxy of innovation.

We then collect national elections and political characteristics data from the 2010 version of the Database of Political Institutions (DPI). Because a national election is our key variable of interest, we restrict our sample to countries with free elections. The intersection of these two databases yields a panel data set of 43 countries over 1976-2010; this data set consists of countries from different continents, cultures, ethnicities, and economies (both developed and emerging).

Our regression results based on country-industry-year observations show that nearly all dimensions of innovations decrease significantly a year after elections (a measure of significant policy uncertainty). We find that the drop is greater for more influential innovations (citations in the right tail, exploratory rather than exploitative innovations) and greater for innovation-intensive industries. These results are new to the literature. Furthermore, our results continue to hold for close presidential elections, which ameliorates some of the endogeneity concerns in our empirical setting. In all these tests, we control for country-industry fixed effects, year fixed effects, and gross domestic product (GDP) growth. With respect to policy, we find that policy does not matter for most dimensions of innovation activities. 
We further mitigate endogeneity concerns by showing that the negative effect of political uncertainty on innovation is stronger among ethnically heterogeneous countries. Because it is difficult to think of an omitted variable that is correlated with (or at least coincidently correlated with) ethnic fractionalization and that affects both policy uncertainty and innovation, this result is consistent with a causal interpretation for the relation between policy uncertainty and innovation.

Finally, we explore one possible underlying mechanism through which policy and policy uncertainty may affect innovation. We find that individuals' incentives to innovate (measured by the numbers of patent inventors that have filed at least 1 patent in the sample year) are negatively affected by policy uncertainty. This finding supports the logic of our theoretical model that policy uncertainty lowers firms' incentives to innovate and, thus, results in fewer inventions. An additional test shows that policy uncertainty adversely affects innovation in the most innovation-intensive industries after we control for country-industry fixed effects and country-year fixed effects; this result confirms our main result. Further tests whose results are documented in the Internet Appendix (available at www.jfqa .org) show that policy uncertainty also adversely affects R\&D spending and growth rates in innovation.

How do we interpret our results in the light of our model? The main testable implication of our model is that policy uncertainty is more important than policy in countries where a political party does not dominate with respect to efficiency in promoting innovation, and vice versa. A country-by-country analysis of our results shows that in 35 of the 43 countries we study no political party dominates with respect to innovation efficiency as measured by patents. Thus, we find that, on average, policy uncertainty affects innovation more than policy does.

Our article contributes to the growing literature on the negative effect of policy uncertainty on the firm's real investment decisions ${ }^{5}$ and to the burgeoning literature on the negative effect of policy uncertainty on stock prices. ${ }^{6}$ Our article also contributes to the literature that links various macroeconomic and firmspecific factors to innovation. ${ }^{7}$ Our article complements this literature by studying

\footnotetext{
${ }^{5}$ On the real investment front, the empirical literature probably starts with Alesina and Perotti (1996), who use data from 70 nations between 1960 and 1985 to show that income inequality increases political instability, which in turn reduces investments. Bloom et al. (2007) use simulated data and show that firms' investment response to stimulus is weaker when uncertainty is higher. In a series of papers, Julio and Yook (2012), (2016) find that during election years, firms reduce capital expenditures as well as foreign direct investment flows to foreign affiliates, as compared to nonelection years. Gulen and Ion (2016) similarly find that policy uncertainty is negatively related to firm- and industry-level capital investment.

${ }^{6}$ On the capital market front, Pastor and Veronesi (2012) build a general equilibrium model to show that announcement of new policy can depress stock returns. Pastor and Veronesi (2013) further show that political uncertainty reduces the value of the implicit put protection offered by the government, which increases the risk premium. Durnev (2011) finds that policy uncertainty reduces firm investment's sensitivity to stock prices. Boutchkova, Doshi, Durnev, and Molchanov (2012) show that both national and global political uncertainty (e.g., national elections) lead to higher stock return volatility. Brogaard and Detzel (2015) find that economic policy uncertainty is negatively (positively) associated with contemporaneous (future) stock returns. Kelly, Pastor, and Veronesi (2014) show that options whose lives span political events, and therefore provide protection against the risk associated with political events, tend to be more expensive.

${ }^{7}$ Existing studies find that financial market development (Hsu et al. (2014)), a larger institutional ownership (Aghion, Van Reenen, and Zingales (2013)), banking competition (Cornaggia, Mao, Tian,
} 
the effect of policy uncertainty on investment in long-term, intangible assets such as technological innovation that is vital for nations' economic growth and competitive advantage. To the best of our knowledge, we are the first to show that innovation, on average, is more affected by policy uncertainty than by policy. Political compromise, we conclude, encourages innovation, and this implication is the most important contribution of our article.

\section{Model}

Edmans (2009) develops a model to argue how the threat of exit by blockholders can ameliorate, not exacerbate, managerial myopia. We borrow some elements of his model: managerial myopia, trade-off between short-term earnings and long-term investments, and the unverifiability of long-term investments. We then add 3 new elements: economic uncertainty, policy, and policy uncertainty. Therefore, our model assumes 6 frictions.

\section{A. Base Case}

As in Edmans (2009), there is a manager who cares about the short-term earnings of the firm at $t=1$ and its long-term value at $t=2$. The respective weights she puts on the short term vis-à-vis the long term are $w$ and $(1-w)$, respectively. The assumed first friction, managerial myopia, is measured by $w$, and the higher the $w$, the greater the myopia.

The manager can invest in a long-term project that unambiguously increases fundamental value in the long run, but risks low earnings in the short run. Slightly departing from Edmans (2009) in our interpretation and parameterization of this project, we interpret our project as innovation. An investment of $\theta$ at $t=0$ in innovation activities is undertaken in a promising new idea. ${ }^{8}$ At $t=1$, with a probability of $\left(1-\theta^{2}\right)$, the idea turns out to be successful, patents are filed, and earnings are $X$; conversely, with a probability of $\theta^{2}$, the idea turns out to be unsuccessful, patents are not filed, and earnings are $a X$, where $a<1$. Therefore, the expected earnings at $t=1$ is

$$
\left(1-\theta^{2}\right) X+\theta^{2} a X .
$$

As $a<1$, it is clear that the expected earnings at $t=1$ given by expression (1) is decreasing in $\theta$. This captures the idea that investments in innovation adversely affect expected short-term earnings. ${ }^{9}$ The assumed second friction, the trade-off between short-run earnings and long-run investments (innovation in our model), is measured by $a$; the lower the $a$, the greater the trade-off.

and Wolfe (2015)), corporate venture capital (Chemmanur, Loutskina, and Tian (2014)), and private rather than public equity ownership (Lerner et al. (2011), Chen et al. (2016)) promote innovation. Other studies examine the effects of product market competition, bankruptcy laws, general market conditions, stock liquidity, firm boundaries, and investors' attitudes toward tolerance on firm innovation (e.g., Aghion, Bloom, Blundell, and Griffith (2005), Acharya and Subramanian (2009), Nanda and Rhodes-Kropf (2013), Fang, Tian, and Tice (2014), Seru (2014), and Tian and Wang (2014)).

${ }^{8}$ Investment in innovation has been regarded as the major capital expenditure in today's knowledge-based economy (Zingales (2000), Lerner and Seru (2015)).

${ }^{9}$ This idea is consistent with current U.S. generally accepted accounting principles (GAAP) that require $R \& D$ spending to be expensed immediately in most cases. 
But investments in innovation do improve expected long-term value. We model this in the following way. If the idea is successful, the long-term value of the firm at $t=2$ is $(X+\theta g) /\left(1-\theta^{2}\right)$. Therefore, long-term value increases as investment $\theta$ at $t=0$ increases. If the idea is not successful, no further investments are made at $t=1$ and the value is 0 at $t+2$. The parameter $g$ is the productivity of the investment in innovation.

Given the manager's myopia, she chooses an investment level $\theta$ at $t=0$ to maximize

$$
w\left\{\left(1-\theta^{2}\right) X+\theta^{2} a X\right\}+(1-w)\left\{\frac{X+g \theta}{\left(1-\theta^{2}\right)}\left(1-\theta^{2}\right)\right\} .
$$

The first-order condition of equation (2) with respect to $\theta$ gives us the investment level the manager would optimally choose at $t=0$ :

$$
\theta=\min \left\{\frac{(1-w) g}{2 w X(1-a)}, 1\right\} .
$$

A few things are to be noted. Although equation (3) is the same as equation (10) in Edmans (2009), our modeling is slightly different. First, his long-run value is certain, which comes from investment in routine tangible assets, whereas our long-run value occurs only if the innovation is successful. Second, our investment is regarded as an investment in innovation, rather than ordinary investment. Thus, our interpretation is different: Because managers are myopic, they will invest less in innovation if their myopia increases or as the trade-off sharpens. This is clear because equation (3) tells us that $\theta$ and $w$ are negatively correlated, and $\theta$ and $(1-a)$ are also negatively correlated.

The wedge, $1-a$, and myopia, $w$, as in Edmans (2009), are two important frictions. Both frictions are observable, and in principle, shareholders and managers can contract around them. What prevents contracting in our model is similar to what prevents contracting in the Edmans model: Investments in R\&D are impossible to interpret, for "[w]hile R\&D can be reported separately on the income statement...they do not know whether a rise in $\mathrm{R} \& \mathrm{D}$ results from managerial excess... or efficient exploitation of new growth opportunities" (Edmans (2009), p. 2499). Thus, the assumed third friction is the unverifiability of investments in innovation.

\section{B. Economic Uncertainty}

We assume up to this point that long-run value will occur for certain at $t=2$ if the idea is successful at $t=1$. We now introduce economic uncertainty in the following way. We assume that, with probability $e$, there is no long-run value at $t=2$, even if the idea is successful at $t=1$. The assumed fourth friction, which we add to the Edmans (2009) model, is economic uncertainty, measured by $e$; the higher the $e$, the greater the economic uncertainty. We note here that because economic uncertainty and policy uncertainty are usually intertwined, the $e$ we model is the economic uncertainty that is orthogonal to policy uncertainty. Given these assumptions, it is easy to see that equation (3) is now modified to

$$
\theta=\min \left\{\frac{(1-w) g(1-e)}{2 w X(1-a)}, 1\right\} .
$$


Equation (4) tells us that investment in innovation decreases as economic uncertainty increases. We focus on the nontrivial case that $\theta=[(1-w) g(1-e)]$ $/[2 w X(1-a)]$ from now on.

\section{Policy and Policy Uncertainty}

We assume that the country we study is a democracy where two parties, $i$ and $j$, vie for power. Each party is associated with a particular policy stance: It prefers a certain type of innovation. In a nonelection year, the innovation policy of the party in power exists, and the productivity of this innovation policy is $g_{i}$ for party $i$ and $g_{j}$ for party $j$. From equation (4), we can observe that the policy difference between the two parties will cause a difference in investment in innovation, expressed as

$$
\left|\theta_{i}-\theta_{j}\right|=\frac{(1-w)(1-e)}{2 w X(1-a)}\left|g_{i}-g_{j}\right| .
$$

This implies that investments in innovation will differ if the innovation productivities under the two parties are different. The key empirical issue is the magnitude of this difference. Therefore, the assumed fifth friction, which we add to the Edmans (2009) model, is different innovation productivities, $g$, under different parties in power. If $g_{i}$ for party $i$ and $g_{j}$ for party $j$ are very different, the parties and their policies will matter for innovation.

In a nonelection year, as the party in power will continue to be the party in power the next year, we assume there is no policy uncertainty. In an election year, as the party in power is not certain to be the party in power next year, there is some policy uncertainty. We model this in the following way. If an investment in innovation is made in an election year under a particular party that prefers that type of innovation, but the other party comes into power in the next year, the longrun value will be lower than what was specified. For simplification, we assume this low value is 0 . The probability that the other party will come into power is $P$. Therefore, if the manager bets on party $i$ coming to power believing that $P$, the probability that party $j$ will come to power, is less than $50 \%$ and invests in innovation accordingly, the expected payoff of the innovation is decreasing as $P$ increases in the range $[0,0.5)$. Correspondingly, if the manager bets on party $j$ coming to power believing that $P$, the probability that party $i$ will come to power, is less than $50 \%$ and invests in innovation accordingly, the expected payoff of the innovation is also decreasing as $P$ increases in the range $[0,0.5)$. The probability $P$ is therefore the policy uncertainty of the economy. The assumed sixth and final friction, which we add to the Edmans (2009) model, is this policy uncertainty, $P$, and the higher the $P$, the greater the policy uncertainty. Again, it is important to emphasize that, as economic uncertainty and policy uncertainty are usually intertwined, the $P$ we model is the policy uncertainty that is orthogonal to economic uncertainty. Hence, these are independent variables. In an election year, therefore, equation (4) is modified to

$$
\theta_{\text {ELECTION }}=\frac{(1-w) g(1-e-P)}{2 w X(1-a)} .
$$

Equation (6) tells us that investment in innovation decreases as policy uncertainty increases. We also note that economic uncertainty and policy uncertainty 
increase the wedge between a firm's long-run fundamental value and short-term earnings estimate from $(1-a)$ to $[1-a] /[1-e-P]$, as $1<1 /[1-e-P]$. From equations (4) and (6), the difference in investment in innovation between an election year and a nonelection year in a particular country, given our definition of $e$ and $P$ being orthogonal to each other, is

$$
\left|\theta_{\text {ELECTION }}-\theta_{\text {NONELECTION }}\right|=\frac{(1-w) g(1-e)}{2 w X(1-a)} P .
$$

So what is more important: policy difference or policy uncertainty? The answer is obtained by comparing the right-hand side of equation (5) with that of equation (7). Policy difference is more (less) important than policy uncertainty if and only if (iff) the right-hand side of equation (5) is greater (less) than the righthand side of equation (7). Simplifying, policy difference is more (less) important than policy uncertainty iff $\left(\left|g_{i}-g_{j}\right|\right) / g$ is greater (less) than $P$. This observation leads to our model implication: policy difference affects innovation more (less) than policy uncertainty in countries where the scaled difference in innovation productivity under the different parties is more (less) than the probability of the party winning that was not expected to win in an election year.

\section{Proxies and Sample Construction}

\section{A. Proxies for Policy and Policy Uncertainty}

Our proxy for policy uncertainty is national elections, both presidential and parliamentary. We focus on election events, instead of numeric political risk indices, in our baseline analysis for several reasons. First, the data on numeric political indices are sparse. ${ }^{10}$ Second, national elections in which political leaders are elected and economic policies are determined serve as an effective setup to examine the effects of policy uncertainty on real activities such as investment and equity trading (e.g., Julio and Yook (2012), Boutchkova et al. (2012)). Third, elections are not subject to biases that occur in survey sampling and model estimation.

We collect this information from the DPI developed by the World Bank (Keefer (2010)), which includes political system, policy orientation, and elections of 180 countries from 1970 to 2010. We use the DPI variable, SYSTEM, and define country $i$ 's political system in year $t\left(\mathrm{SYSTEM}_{i, t}\right)$ as the value of SYSTEM in country $i$ in year $t$. We use the DPI categorization for SYSTEM: Presidential (0), assembly-elected president (1), and parliamentary (2). ${ }^{11}$ We again

\footnotetext{
${ }^{10}$ The economic policy uncertainty indices developed by Baker, Bloom, and Davis (2016) cover only 9 countries: Canada, China, France, Germany, India, Italy, Spain, the United Kingdom, and the United States. Among these covered countries, only China and India are developing economies, and their time-series indices are short (the indices for China and India start from 1995 and 2003, respectively).

${ }^{11}$ Presidential system is defined as i) countries with unelected executives, ii) countries with presidents who are elected directly or by an electoral college in cases where there is no prime minister, and iii) countries with both a prime minister and a president, but the president can veto legislation, can appoint and dismiss a prime minister, or can dissolve parliament and call for new elections. Parliamentary system is defined as countries in which the legislature elects the chief executive and can easily recall the chief executive. Assembly-elected presidential system is defined as countries in which the legislature elects the chief executive and cannot easily recall the chief executive.
} 
use the DPI data, legislative election years or executive election years to define election years, to construct our proxy for policy uncertainty, which is the election dummy (ELECTION ${ }_{i, t}$ ) that equals 1 if country $i$ holds any presidential election for countries adopting the presidential system in year $t$, or parliamentary election for countries adopting the parliamentary or assembly-elected president system, and 0 otherwise.

The DPI also categorizes the party orientation of country executives (presidents or prime ministers) into 3 major groups using a consistent standard: Right (1), center (2), and left (3). ${ }^{12}$ Similarly, the DPI categorizes the party orientation of government parties into right (1), center (2), and left (3). To interpret these values more intuitively, we shift the values of these two party orientations from right (1), center (2), and left (3), to right $(-1)$, center (0), and left (1). We then define country $i$ 's policy in year $t$ (POLICY $\left.{ }_{i, t}\right)$ as the party orientation of executives of country $i$ on Jan. 1 in year $t$; when the party orientation of executives of country $i$ in year $t$ is missing, we let POLICY $_{i, t}$ equal the party orientation of government parties of country $i$ on Jan. 1 in year $t$.

We note that the DPI adopts a country-specific standard to assign political orientation; it is possible in its classifications that the policies of one country's right-wing parties may be more left than the policies of another country's leftwing parties (e.g., in many dimensions, the right-wing Christian Democrats in Germany are more "left" than the left-wing Democrats in the United States). It should also be noted that this does not matter in our analysis of policy, as we use country-adjusted innovation in the univariate analysis and country fixed effects in the multivariate analysis. Furthermore, though we follow the DPI's classifications to label policies as "left," "center," and "right" (or even random letters such as "x," "y," or "z"), we do not overstate the interpretations of our results under this classification.

\section{B. Proxies for Industry-Level Innovation}

We construct empirical proxies for industry-level innovation using the Harvard Business School Patent Inventor Database of Li, Lai, D'Amour, Doolin, Sun, Torvik, Yu, and Fleming (2014), which contains detailed information of patents granted by the U.S. Patent and Trademark Office (USPTO) from 1976 to 2010. The use of U.S. patents provides us a common standard to measure industry-level innovation activities because some countries adopt technology classifications different from those used in the United States. Moreover, by using U.S. patents, we ensure the consistency and comparability of the quality, economic value, legal protection, and application procedure in patent output across different economies (e.g., Jaffe and Trajtenberg (2002), Lerner (2009)). ${ }^{13}$

\footnotetext{
${ }^{12}$ Right denotes parties that are defined as right wing, Christian democratic, or conservative. Left denotes parties that are defined as left wing, communist, socialist, or social democratic. Center denotes parties that are defined as centrist or when party position can best be described as centrist. There is another category "Other" that includes all those cases that do not fit into the above-mentioned 3 categories. We exclude the "Other" category from our sample because our main goal is to understand the policy-innovation relation.

${ }^{13}$ As discussed before, using U.S. patent data to measure cross-country innovation performance is widely adopted in recent studies (e.g., Griffith, Harrison, and Van Reenen (2006), Acharya and Subramanian (2009), and Hsu et al. (2014)). This approach is commonly adopted in the literature
} 
We collect the detailed data of individual patents including 3-digit technology classes from the National Bureau of Economic Research (NBER) patent database during 1976-2010. We use the mapping method developed in Hsu et al. (2014) to assign U.S. patents to corresponding 2-digit Standard Industrial Classification (SIC) industry codes because the USPTO adopts a 3-digit class system that is based on technology categorization instead of final-product categorization. We follow the literature and restrict our sample to manufacturing industries of 2-digit SIC codes between 20 and 39.

We examine whether the policy and policy uncertainty in year $t$ affects innovation in year $t+1 .{ }^{14}$ We measure innovation activities of industry $j$ in country $i$ in year $t+1$ as the value of the following patent-based measures that are invented by residents of country $i$ and filed with the USPTO in industry $j$ in year $t+1$ : the number of patents $\left(\operatorname{PATENT}_{j, i, t+1}\right)$, the number of citations received by granted patents $\left(\mathrm{CITATION}_{j, i, t+1}\right)$, the originality score of patents (ORIGINALITY OR,itt $_{1}$ ), the number of patents in the top quartile of citations (CITATION_TOP_25_PCT ${ }_{j, i, t+1}$ ), the number of patents in the bottom quartile of citations (CITATION_BOTTOM 25 PCT $_{j, i, t+1}$ ), the standard deviation of citations (CITATION_STD_DEV $V_{j, i, t+1}$ ), the number of exploratory patents $\left(\right.$ EXPLORATION $\left._{j, i, t+}\right)$, and the number of exploitative patents $\left(\right.$ EXPLOITATION $\left._{j, i, t+1}\right)$.

PATENT $_{j, i, t+1}$ denotes the number of successful patent applications that are filed with the USPTO in year $t+1$, are classified in industry $j$, and are invented by residents of country $i$. Despite the straightforward interpretation of PATENT $_{j, i, t+}$, we recognize that patent counts do not identify the influence of groundbreaking inventions. Therefore, we consider the number of forward citations received by granted patents $\left(\right.$ CITATION $\left._{j, i, t+1}\right)$, which is defined as the number of adjusted citations received by patents that are invented by residents of country $i$ and filed with the USPTO in industry $j$ in year $t+1 .^{15}$ As suggested in prior studies (e.g., Trajtenberg (1990), Harhoff, Narin, Scherer, and Vopel (1999), and Aghion et al. (2013)), patent citations reflect the influence of inventions and better capture the quality of aggregate innovation and its market value.

In addition to the quantity and quality of patents, we consider patent originality, which reflects the fundamental value of innovation. Following Hall et al. (2001), we define a patent's originality score as 1 minus the Herfindahl index

because the territorial principle in U.S. patent laws requires anyone intending to claim exclusive rights for inventions in the United States to file U.S. patents. Following prior studies, we assume that all important inventions from other countries have been patented in the United States because the United States has been the largest technology consumption market in the world over the past few decades.

${ }^{14}$ This assumption is based on evidence. Although it takes time for policy and policy uncertainty to affect innovation activities, prior studies suggest that the average lag between R\&D investment and patent applications is often within 1 year (see Hausman, Hall, and Griliches (1984), Hall, Griliches, and Hausman (1986)). This viewpoint is widely accepted in contemporary empirical studies for the determinants of innovation in high-tech industries (e.g., Lerner and Wulf (2007), Aghion et al. (2013), and Bloom, Schankerman, and Van Reenen (2013)). Thus, it seems reasonable to assume that policy and policy uncertainty in year $t$ affect patent filings in year $t+1$.

${ }^{15}$ This measure is sometimes referred to as "citation-based patent counts" in the literature. Because our patent database tracks citations until 2014, we must appropriately adjust for such a truncation bias. Therefore, we use a weighting factor developed by Hall, Jaffe, and Trajtenberg (2001) to adjust the number of patent citations. 
of the 6 technology categories distribution of all the patents it cites. A high originality score suggests the patent is based on a more diverse array of existing technologies; thus, the patent is considered to be more original because it follows traditional technology trajectories less. The existing literature has shown that innovation often demands the use of multidisciplined knowledge (Arora and Gambardella (1990), Ahuja (2000)), and patents with higher originality scores tend to carry higher market value (Hirshleifer, Hsu, and Li (2017)). We then aggregate individual patents' originality scores at the industry-country level and compute our third innovation measure, ORIGINALITY ${ }_{j, i, t+1}$, which denotes the sum of the originality scores of all patents invented by residents of country $i$ and filed with the USPTO in industry $j$ in year $t+1$.

CITATION_TOP_25_PCT T $_{j, t+1+1}$ denotes the number of patents applied for (and subsequently granted) whose forward citations are above the 75th percentile of the citation distribution in year $t+1$ in industry $j$. CITATION BOTTOM_25_PCT , $_{j, t+1+1}$ denotes the number of patents applied for (and subsequently granted) whose forward citations are below the 25 th percentile of the citation distribution in year $t+1$ in industry $j$. CITATION_STD_DEV , $_{j, i, t+1}$ denotes the standard deviation of citation distribution in year $t+1$ in industry $j$. These 3 metrics measure the riskiness and skewness of the innovation, and we use them to capture the notion that political uncertainty may curb not only the level of innovation, but also risky and potentially influential innovations. EXPLOITATION EXi,t+1 $_{j}$ denotes the number of patents in industry $j$ in year $t+1$ that make at least one self-citation, reflecting innovation activities that are built on the existing knowledge of organizations. Conversely, EXPLORATION ${ }_{j, i, t+1}$ denotes the number of patents in industry $j$ in year $t+1$ that do not make any self-citation, reflecting innovation activities that are beyond the existing knowledge of organizations. These 2 metrics help us examine whether political uncertainty influences the trajectories and evolutions of knowledge development. Collectively, these 5 metrics are inspired by Chava et al. (2013) and Balsmeier, Fleming, and Manso (2017).

Two issues about our innovation measures are worth discussing. First, we calculate the number of patents and other patent-based measures based on application years instead of grant years because the application years are better aligned with the time when firms make their decisions (Griliches, Pakes, and Hall (1988), Hall et al. (2001), (2005)). Second, we assign patents to countries by their inventors, so we avoid a potential sampling bias, for some multinational enterprises outsource their research activities overseas (see Chung and Alcácer (2002)) or have multiple research centers. In fact, our data show that $57.5 \%$ of patents come from multinational companies/institutes (defined as patent assignees with inventors in different countries). We also make this choice because of data limitations, as the country information of $15.8 \%$ of patent assignees is missing in the NBER patent database of Hall et al. (2001).

\section{Sample Construction}

We obtain data on the top 60 patent-filing economies with the most patents granted by the USPTO over 1976-2010. ${ }^{16}$ Among the top 60 economies in the

\footnotetext{
${ }^{16} \mathrm{http}: / /$ www.uspto.gov/web/offices/ac/ido/oeip/taf/h_at.htm.
} 
USPTO, we exclude China, Hong Kong, Kuwait, Saudi Arabia, and United Arab Emirates (UAE) because DPI provides no election data for these countries/economies. We also exclude Belgium, Cuba, Iran, Taiwan, and Thailand because there is only one party orientation (right, left, or center) in these countries/economies. Next, we exclude Egypt, Indonesia, Malaysia, and Singapore because their respective party orientations are categorized as "Other" across all years. Note that we have to exclude the above economies because we cannot run a "horse race" between policy and policy uncertainty if policies fail to change. We also exclude the Czech Republic, Slovenia, and Yugoslavia because of data availability issues. These filtrations then lead to the following 43 countries in our final sample: Argentina, Australia, Austria, Brazil, Bulgaria, Canada, Chile, Colombia, Croatia, Denmark, Finland, France, Germany, Greece, Hungary, Iceland, India, Ireland, Israel, Italy, Japan, Luxembourg, Mexico, Netherlands, New Zealand, Norway, Pakistan, Philippines, Poland, Portugal, Romania, Russia, South Africa, South Korea, Spain, Sweden, Switzerland, Turkey, Ukraine, United Kingdom, United States, Uruguay, and Venezuela.

Our final data set is a country-industry panel of these 43 countries. Our panel contains annual data for these 43 counties on their political systems, policies, policy uncertainty (election year), and various innovation measures from 1976 to 2010. An important control variable is the annual growth in GDP, because this variable is likely to correlate with subsequent innovation. $\mathrm{GDP}_{i, t}$ denotes the growth of GDP in country $i$ in year $t$, which is collected from the World Development Indicators and Global Development Finance database.

\section{Summary Statistics}

Table IA1 in the Internet Appendix shows the time-series averages and standard deviations of the country-level political, economic, and innovation variables. The columns under SYSTEM in Table IA1 show that 29 countries have never changed their political systems throughout the sample period; among them, 10 countries adopt the presidential system (0) in all years, and 19 countries adopt the parliamentary system (2) in all years. The columns under POLICY in Table IA1 show that all countries have switched between policies (this is by sample construction), some more frequently than others. We find that the frequency of right-wing governments is higher than that of left-wing governments in our sample countries: 25 countries have an average under 0 , and 18 countries have an average over 0 (recall that we code the right as -1 and the left as 1 ). The columns under ELECTION in Table IA1 show that Australia and Denmark have the highest election frequency ( 0.34 , which means about 1 election every 3 years). We also find that South Korea has the highest GDP growth on average (6.7\% per year), whereas Ukraine is the only country with negative average GDP growth $(-1.0 \%$ per year) in the sample period.

Table IA1 also provides the averages and standard deviations of the countryand industry-level innovation measures. The United States and Japan are consistently ranked at the top and second across all innovation measures. Overall, Table IA1 presents substantial variation in political and innovation variables. 


\section{Results}

Our model implies that policy difference affects innovation more (less) than policy uncertainty in countries where the scaled difference in innovation under the different parties is more (less) than the probability of the party winning that was not expected to win in an election year. In this section, we empirically test this model implication. In Section IV.A, we first present univariate comparisons to understand the relation between policy and innovation in individual countries. In Section IV.B, we employ multivariate regressions to conduct a more formal analysis of the average effect of policy and policy uncertainty on innovation. In Section IV.C, we focus on the average effect of close elections on innovation to strengthen a causal interpretation for our baseline results. Section IV.D presents the results from the subsample analysis based on ethnic fractionalization. In Section IV.E, we examine an inventor's incentive to innovate. In Section IV.F, we examine the heterogeneous effects of policy uncertainty on innovation across different industries. Section IV.G presents more robustness checks.

\section{A. Univariate Analysis for Policy and Innovation within Individual Countries}

For a univariate analysis for the policy-innovation relation, we start with INNOVATION $_{j, i, t+1}$, and then sum patent-based variables across all industries $j$ in

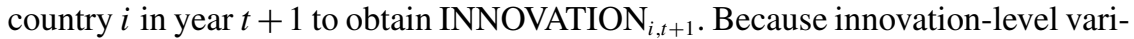
ables grow persistently over time, we detrend INNOVATION INtt+1 $_{1}$ using an AR(1) model. We then assign all innovation measures into 3 policy groups, that is, left, center, or right, based on country $i$ 's policy orientation in year $t$. Then, for each country, we conduct $t$-tests to examine whether a particular policy group is associated with significantly higher innovation activities than the other groups. ${ }^{17}$ Table 1 reports these results.

In Panel A of Table 1, we find that the left policy is associated with more (fewer) patents in Chile (Argentina and South Africa), the center policy is associated with more (fewer) patents in Italy (Chile, Croatia, and Poland), and the right policy is associated with more (fewer) patents in South Africa (Finland, Italy, and Sweden). When we pool all country-year observations for all 43 countries for the sake of comparison and report the results in the top row of Panel A ("All"), we find that the average is $-2.4 \%, 0.8 \%$, and $-11.3 \%$, under left-center, center, and right-center policies, respectively; however, the differences are not statistically significant. In other words, no policy dominates or subordinates others in terms of number of patents filed under that policy in the average country.

In Panel B of Table 1, we find that the left policy is associated with more (fewer) citations in Israel (Uruguay), the center policy is associated with more citations in Colombia and Spain, and the right policy is associated with more (fewer) citations in Uruguay (Colombia, Israel, and Spain). As in Panel A, we find no policy that dominates or subordinates others in terms of citations in the average country.

\footnotetext{
${ }^{17}$ Whenever there is an election in country $i$ in year $t$, we exclude innovation variables in country $i$ in year $t-1, t$, and $t+1$ from our sample for 2 reasons: First, innovation in these countries may be affected by policy uncertainty rather than by policy differences, and second, it is difficult to relate innovation to a particular policy when policy changes because of elections.
} 
In Panels $\mathrm{C}-\mathrm{H}$ of Table 1, we report the comparison at the country level and the aggregate level of other innovation variables including ORIGINALITY I $_{j, i, t+1}$, CITATION_TOP_25_PCT , $_{j, i, t+1}$, CITATION BOTTOM_25_PCT ${ }_{j, i, t+1}$, CITATION_STD_DEV ${ }_{j, i, t+1}$, EXPLORATION $_{j, i, t+1}$, and EXPLOITATION $_{j, i, t+1}$. At the country level, we find only a few countries with a

\section{TABLE 1}

\section{Univariate Analysis for the Relation between Policy and Innovation}

Table 1 reports for 43 countries the time-series averages of INNOVATION ${ }_{i, t+1}$ given country i's policy orientation $\left(\mathrm{POLICY}_{i, t}\right.$ ) on Jan. 1 of year $t$. Here, $i$ denotes a country, and $i=1,2, \ldots, 43$. $t$ denotes a year and ranges from 1976 to 2010. INNOVATION* ${ }_{i, t+1}$ is the detrended innovation level of PATENT $T_{i, t+1}$, CITATION $_{i, t+1}$, ORIGINALITY $Y_{i, t+1}$, CITATION_TOP_25_PCT $T_{i, t+1}, \quad$ CITATION_BOTTOM_25_PCT $i, t+1$, CITATION_STD_DEV $V_{i, t+1}, \quad$ EXPLORATION ${ }_{i, t+1}$, and EXPLOITATION ${ }_{i, t+1}$ plus 1 in logarithm of country $i$ in year $t+1$. For each innovation variable, we run autoregressive regressions to calculate the intercept term and $A R(1)$ coefficient and then use the regression residuals as the detrended innovation level. The first 3 columns in each panel report the time-series averages of each country's annual INNOVATION* ${ }_{i+t+1}$ when the country adopts left, center, and right policies in year $t$, respectively. The last 3 columns in each panel report the $t$-statistics of the difference in innovation among different policies. ${ }^{* *}$ and ${ }^{* * *}$ indicate statistical significance at the $5 \%$ and $1 \%$ levels, respectively. Estimates reported in the row labeled "All" are based on all country-year observations.

\begin{tabular}{|c|c|c|c|c|c|c|c|c|c|c|c|c|}
\hline 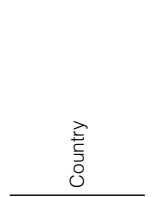 & $\stackrel{ \pm}{\oplus}$ & 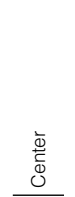 & 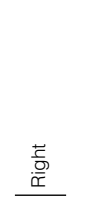 & 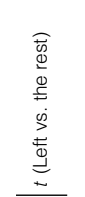 & 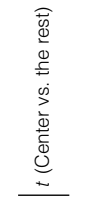 & 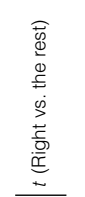 & $\stackrel{ \pm}{\Xi}$ & 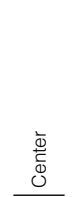 & 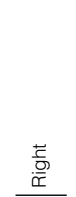 & 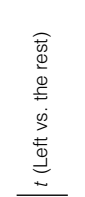 & 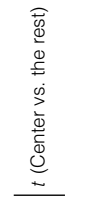 & 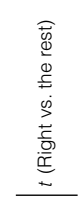 \\
\hline & \multicolumn{6}{|c|}{ Panel A. PATENT } & \multicolumn{6}{|c|}{ Panel B. CITATION } \\
\hline All & -0.024 & 0.008 & -0.113 & 0.73 & 0.88 & -1.43 & -0.007 & 0.041 & 0.041 & -0.50 & 0.21 & 0.34 \\
\hline Argentina & -0.337 & 0.182 & 0.171 & $-2.18^{\star \star}$ & 0.93 & 1.19 & -0.370 & 0.458 & 0.014 & -1.50 & 1.53 & 0.09 \\
\hline & 0.111 & & 0.111 & 1.45 & & 1.45 & & & & -0.34 & & \\
\hline ustria & 0.024 & & -0.107 & 0.63 & & -0.63 & 0.029 & & -0.126 & 1.20 & & -1.20 \\
\hline B & -0.069 & & 0.062 & -0.98 & & 0.98 & -0.22 & & 0.200 & -1.87 & & 1.87 \\
\hline Bulgaria & 0.071 & & -0.238 & 1.10 & & -1.10 & 0.149 & & -0.246 & 0.96 & & -0.96 \\
\hline Canada & 0.101 & & -0.139 & 1.50 & & -1.50 & -0.018 & & 0.024 & -0.29 & & 0.29 \\
\hline $\begin{array}{l}\text { Chile } \\
\text { Colombia }\end{array}$ & 0.265 & $\begin{array}{r}-0.523 \\
0.079\end{array}$ & $\begin{array}{r}-0.091 \\
0.079\end{array}$ & $2.17^{\star \star}$ & $\begin{array}{c}-2.05^{\star \star} \\
0.00\end{array}$ & $\begin{array}{r}-0.63 \\
0.00\end{array}$ & 0.077 & $\begin{array}{r}-0.149 \\
0.377\end{array}$ & $\begin{array}{l}-0.028 \\
-0.563\end{array}$ & 0.42 & $\begin{array}{l}-0.39 \\
2.20^{\star \star}\end{array}$ & $\begin{array}{l}-0.14 \\
-2.20^{\star \star}\end{array}$ \\
\hline Croatia & 0.130 & -1.657 & 0.218 & 0.21 & $-3.89^{\star \star \star}$ & 2.03 & -0.456 & -1.451 & 0.521 & -0.81 & -1.69 & 1.88 \\
\hline & -0.014 & & 0.010 & -0.18 & & 0.18 & -0.084 & & 0.061 & -0.77 & & 0.77 \\
\hline Finland & 0.138 & -0.034 & -0.483 & 1.78 & -0.38 & -2.32 & 0.080 & -0.024 & -0.263 & 0.87 & -0.23 & -1.05 \\
\hline France & 0.091 & & -0.059 & 1.10 & & -1.10 & -0.032 & & 0.021 & -0.77 & & 0.77 \\
\hline & 0.046 & & -0.030 & 0.59 & & -0.59 & -0.030 & & 0.020 & -0.64 & & 0.64 \\
\hline & -0.031 & & 0.027 & -0.31 & & 0.31 & -0.034 & & 0.031 & -0.21 & & 0.21 \\
\hline Hungary & 0.052 & & -0.278 & 1.58 & & -1.58 & -0.023 & & 0.122 & -0.67 & & 0.67 \\
\hline Iand & & 0.058 & 0.096 & & -0.18 & 0.18 & & -0.012 & 0.176 & & -0.43 & 0.43 \\
\hline Indi & -0.053 & & 0.285 & -1.29 & & 1.29 & 0.007 & & -0.035 & 0.12 & & -0.12 \\
\hline Ireland & & 0.037 & -0.070 & & 0.65 & -0.65 & & -0.025 & 0.048 & & -0.26 & 0.26 \\
\hline & 0.152 & & -0.047 & 1.18 & & -1.18 & 0.320 & & -0.099 & $2.65^{\star \star \star}$ & & $-2.65^{\star \star \star}$ \\
\hline Italy & 0.126 & 0.191 & -0.423 & 0.83 & $2.64^{\star \star \star}$ & $-4.13^{\star \star}$ & 0.099 & 0.028 & -0.120 & 0.59 & 0.32 & -0.89 \\
\hline & 0.076 & & 0.107 & -0.25 & & 0.25 & -0.246 & & 0.048 & -1.35 & & 1.35 \\
\hline Luxembourg & & -0.041 & 0.274 & & -1.37 & 1.37 & & -0.030 & 0.196 & & -0.73 & 0.73 \\
\hline & -0.019 & 0.183 & -0.262 & -0.10 & 1.90 & -1.95 & 0.142 & 0.064 & -0.191 & 1.10 & 0.90 & -2.01 \\
\hline erlands & 0.063 & & -0.029 & 0.45 & & -0.45 & -0.097 & & 0.045 & -1.30 & & 1.30 \\
\hline d & 0.017 & & -0.013 & 0.24 & & -0.24 & -0.095 & & & -0.79 & & 0.79 \\
\hline wa & -0.083 & & 0.143 & -0.89 & & 0.89 & 0.016 & & -0.027 & 0.31 & & -0.31 \\
\hline & -0.202 & & 0.256 & -0.85 & & 0.8 & -0.436 & & & -1.03 & & 1.03 \\
\hline opines & & 0.044 & 0.052 & & -0.03 & 0.03 & & -0.097 & 0.237 & & -0.87 & \\
\hline & 0.103 & -1.830 & 0.095 & 1.92 & $-5.26^{\star \star \star}$ & 0.38 & 0.108 & -0.832 & -0.263 & 1.68 & -1.57 & -0.89 \\
\hline & 0.093 & -0.237 & -0.07 & 0.80 & -0.56 & -0.5 & 0.011 & -0.1 & & 0.07 & -0.19 & 0. \\
\hline ania & -0.108 & 0.216 & 0.257 & -1.19 & 0.79 & 0.68 & -0.123 & 0.450 & 0.786 & -1.26 & 0.64 & 0.95 \\
\hline Rus: & & -0.216 & 0.256 & & -1.43 & 1.43 & & 0.065 & -0.019 & & 0.19 & -0.19 \\
\hline South Africa & -0.133 & & 0.119 & $-2.23^{\star \star}$ & & $2.23^{\star \star}$ & -0.138 & & 0.124 & -1.58 & & 1.58 \\
\hline h Korea & & 0.185 & -0.085 & & 1.52 & -1.52 & & -0.022 & & & -0.11 & \\
\hline & 0.051 & & -0.1 & 0.77 & 0.14 & -0.9 & 0.039 & 0.400 & -0.3 & 0.80 & $2.10^{\star \star}$ & $-2.73^{\star \star}$ \\
\hline & 0.068 & 0.266 & -0.33 & 1.15 & 1.34 & $-2.52^{\star \star}$ & -0.054 & 0.228 & 0.0 & -0.80 & 1.01 & 0.11 \\
\hline & 0.062 & & & -1.68 & -0.42 & 1.88 & -0.068 & 0.311 & -0.054 & -0.52 & 1.80 & -0.10 \\
\hline Turke & 0.209 & -0.332 & 0.044 & 0.73 & -1.18 & 0.27 & 0.118 & -0.571 & 0.295 & -0.01 & -1.10 & 0.83 \\
\hline & 0.285 & -0.092 & & 1.35 & -1.35 & & 0.630 & 0.046 & & 0.61 & -0.61 & \\
\hline United & -0.088 & & 0.079 & -1.41 & & 1.41 & 0.060 & & -0.054 & 0.66 & & -0.66 \\
\hline d States & -0.131 & & 0.095 & -1.63 & & 1.63 & -0.101 & & 0.073 & -1.47 & & 1.47 \\
\hline & 0.138 & & 0.118 & 0.07 & & -0.07 & -0.780 & & 0.505 & $-2.29^{\star \star}$ & & $2.29^{\star \star}$ \\
\hline Venezuela & 0.117 & & 0.171 & -0.34 & & 0.34 & 0.141 & & 0.249 & -0.30 & & 0.30 \\
\hline
\end{tabular}


TABLE 1 (continued)

Univariate Analysis for the Relation between Policy and Innovation

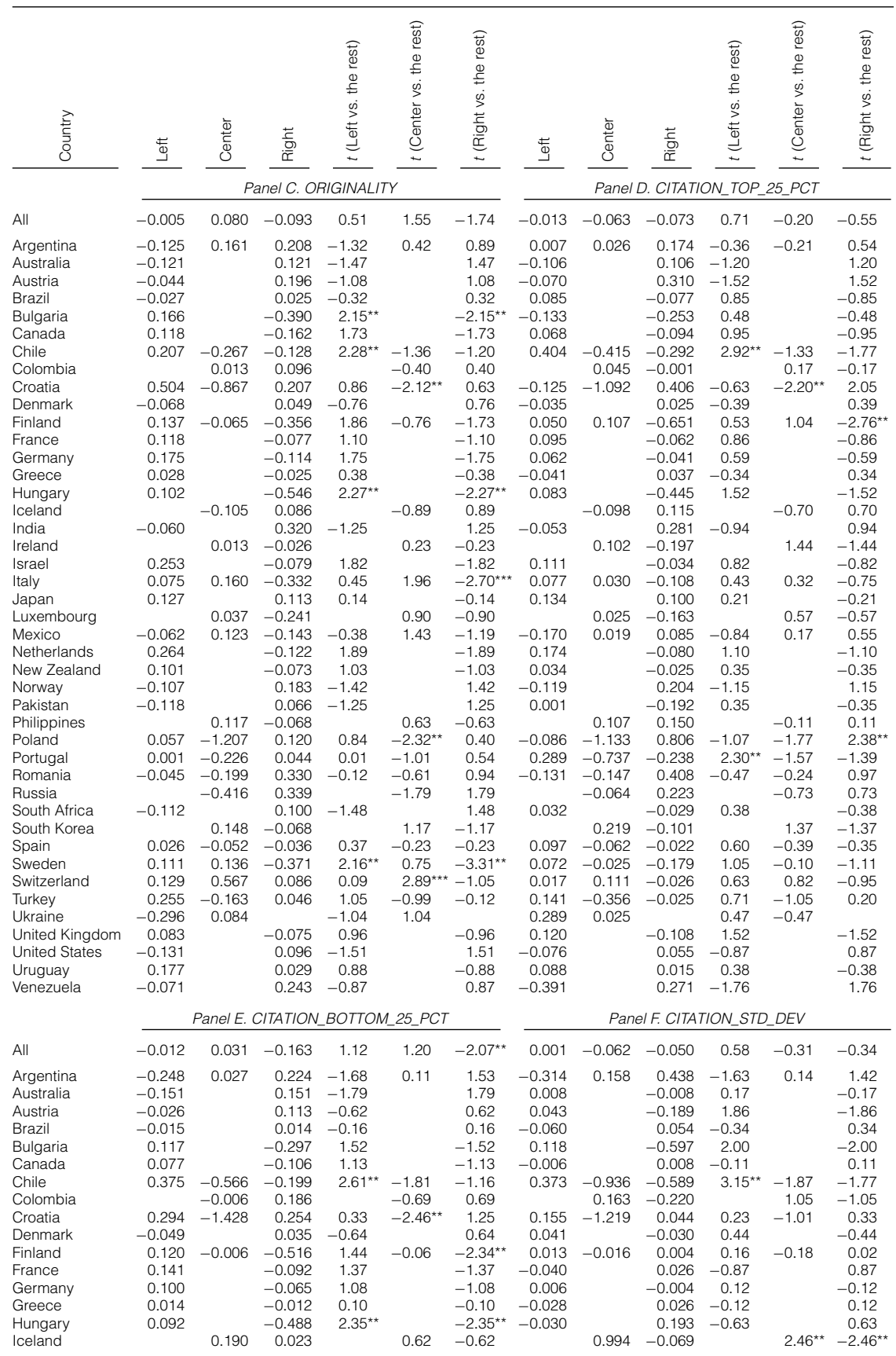




\section{TABLE 1 (continued)}

Univariate Analysis for the Relation between Policy and Innovation

\begin{tabular}{|c|c|c|c|c|c|c|c|c|c|c|c|c|}
\hline 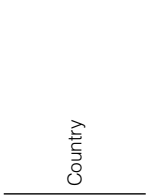 & $\stackrel{\overrightarrow{0}}{\lrcorner}$ & $\begin{array}{l}\stackrel{\Phi}{ \pm} \\
\stackrel{D}{D} \\
0\end{array}$ & $\begin{array}{l}\frac{\vec{t}}{\sigma} \\
\frac{\sigma}{\tilde{I}}\end{array}$ & 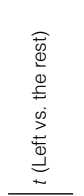 & 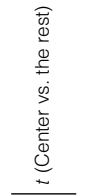 & 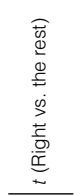 & $\stackrel{ \pm \Phi}{\lrcorner}$ & 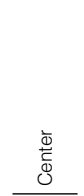 & $\begin{array}{l}\frac{ \pm}{5} \\
\frac{\sigma}{\square} \\
\end{array}$ & 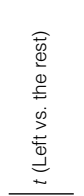 & 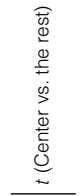 & 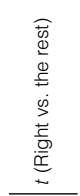 \\
\hline & \multicolumn{6}{|c|}{ Panel E. CITATION_BOTTOM_25_PCT (continued) } & \multicolumn{6}{|c|}{ Panel F. CITATION_STD_DEV (continued) } \\
\hline India & -0.051 & & 0.273 & -1.09 & & 1.09 & -0.054 & & 0.286 & -0.67 & & 0.67 \\
\hline Ireland & & 0.075 & -0.143 & & 1.10 & -1.10 & & -0.081 & 0.156 & & -0.63 & 0.63 \\
\hline Israel & 0.070 & & -0.022 & 0.44 & & -0.44 & 0.100 & & -0.031 & 0.87 & & -0.87 \\
\hline aly & 0.142 & 0.146 & -0.355 & 0.85 & 1.74 & $-2.89^{\star \star}$ & 0.021 & 0.005 & -0.0 & 0.19 & 0.09 & -0.27 \\
\hline Japan & 0.155 & & 0.103 & 0.56 & & -0.56 & -0.079 & & 0.018 & -1.05 & & 1.05 \\
\hline Luxembourg & & 0.018 & -0.118 & & 0.43 & -0.43 & & -0.008 & 0.048 & & -0.16 & 0.16 \\
\hline Mexico & -0.169 & 0.107 & -0.047 & -0.85 & 0.98 & -0.31 & -0.128 & 0.388 & -0.497 & -0.39 & $2.29^{\star \star \star}$ & $-2.07^{\text {ᄎ* }}$ \\
\hline letherlands & 0.140 & & -0.065 & 0.87 & & -0.87 & -0.068 & & 0.031 & -1.25 & & 1.25 \\
\hline ew Zealand & 0.074 & & -0.054 & 0.71 & & -0.71 & -0.043 & & 0.031 & -0.38 & & 0.38 \\
\hline orway & -0.096 & & 0.164 & -0.98 & & 0.98 & -0.047 & & 0.077 & -0.91 & & 0.91 \\
\hline akistan & -0.016 & & 0.100 & -0.19 & & 0.19 & -0.534 & & & & & \\
\hline Philippines & & 0.258 & -0.257 & & 1.41 & -1.41 & & 0.061 & -0.041 & & 0.15 & -0.15 \\
\hline oland & 0.051 & -1.694 & 0.309 & 0.82 & $-3.88^{\star \star}$ & 1.11 & 0.128 & -1.611 & & 1.69 & -1.71 & -1.02 \\
\hline Portugal & 0.064 & -0.399 & -0.006 & 0.46 & -0.80 & -0.03 & 0.100 & -0.818 & -0.065 & 0.49 & -0.68 & -0.24 \\
\hline Romania & -0.121 & 0.008 & -0.061 & -0.31 & 0.31 & 0.05 & -0.217 & -0.189 & 0.724 & -0.74 & -0.26 & 1.33 \\
\hline Russia & & -0.188 & 0.188 & & -1.07 & 1.07 & & -0.141 & -0.044 & & -0.39 & 0.39 \\
\hline outh Africa & -0.158 & & 0.143 & $-2.23^{\star \star}$ & & $2.23^{\star \star}$ & -0.129 & & 0.116 & -1.35 & & 1.35 \\
\hline South Korea & & 0.225 & -0.104 & & 1.55 & -1.55 & & 0.027 & -0.013 & & 0.11 & -0.11 \\
\hline pain & 0.078 & -0.082 & -0.1 & 1.01 & -0.39 & -0.81 & 0.011 & 0.343 & -0.099 & -0.19 & 1.06 & -0.62 \\
\hline den & 0.108 & 0.162 & -0.378 & 1.77 & 0.76 & $-2.78^{\star \star \star}$ & -0.043 & 0.165 & 0.023 & -1.22 & 1.40 & 0.28 \\
\hline zerland & 0.092 & -0.131 & 0.148 & -0.67 & -1.81 & 1.35 & -0.040 & 0.190 & -0.018 & -0.46 & 0.98 & 0.11 \\
\hline urker & 0.067 & -0.147 & 0.000 & 0.29 & -0.44 & 0.10 & 0.047 & & 0.278 & -0.25 & & 0.25 \\
\hline Ukra & 0.920 & -0.064 & & 1.95 & -1.95 & & 0.445 & 0.058 & & 0.41 & -0.41 & \\
\hline United Kingdom & 0.024 & & -0.021 & 0.33 & & -0.33 & 0.082 & & -0.074 & 1.76 & & -1.76 \\
\hline United States & -0.121 & & 0.088 & -1.47 & & 1.47 & -0.022 & & 0.016 & -0.89 & & 0.89 \\
\hline Uruguay & 0.386 & & 0.013 & 1.20 & & -1.20 & -0.077 & & 0.061 & -0.91 & & 0.91 \\
\hline \multirow[t]{2}{*}{ Venezuela } & -0.034 & & 0.347 & -1.13 & & 1.13 & -0.012 & & 0.247 & -0.48 & & 0.48 \\
\hline & \multicolumn{6}{|c|}{ Panel G. EXPLORATION } & \multicolumn{6}{|c|}{ Panel H. EXPLOITATION } \\
\hline All & -0.032 & -0.003 & -0.126 & 0.76 & 0.85 & -1.44 & 0.093 & 0.067 & -0.044 & 1.40 & 0.48 & 1.75 \\
\hline & 0.324 & 0.191 & 0.162 & $-2.11^{\star \star}$ & 0.96 & 1.10 & -0.248 & -0.076 & 0.357 & -1.54 & -0.46 & 1.99 \\
\hline & -0.107 & & 0.107 & -1.42 & & 1.42 & -0.153 & & 0.153 & -1.35 & & 1.35 \\
\hline ustria & 0.009 & & -0.040 & 0.23 & & -0.23 & 0.000 & & 0.002 & -0.01 & & 0.01 \\
\hline & -0.062 & & 0.056 & -0.91 & & 0.91 & -0.054 & & 0.048 & -0.43 & & 0.43 \\
\hline & 0.066 & & -0.233 & 1.07 & & -1.07 & 0.098 & & -0.328 & 1.46 & & -1.46 \\
\hline Canada & 0.100 & & -0.138 & 1.48 & & -1.48 & 0.178 & & -0.245 & 1.83 & & -1.83 \\
\hline Chile & 0.313 & -0.596 & -0.117 & $2.47^{\star \star}$ & $-2.23^{\star \star}$ & -0.77 & 0.032 & 0.228 & -0.128 & 0.39 & 1.37 & -1.44 \\
\hline Colombia & & 0.068 & 0.093 & & -0.11 & 0.11 & & 0.082 & -0.098 & & 0.94 & -0.94 \\
\hline Croatia & 0.191 & -1.647 & 0.217 & 0.31 & $-3.74^{\star \star \star}$ & 1.85 & -0.041 & -0.097 & 0.109 & -0.32 & -0.39 & 0.53 \\
\hline & -0.024 & & 0.018 & -0.32 & & 0.32 & 0.177 & & -0.129 & 1.56 & & -1.56 \\
\hline Finland & 0.138 & -0.023 & -0.529 & 1.77 & -0.25 & $-2.56^{\star \star}$ & 0.127 & -0.230 & 0.347 & 1.28 & $-2.17^{\star \star}$ & 1.26 \\
\hline & 0.116 & & -0.076 & 1.40 & & -1.40 & 0.097 & & -0.063 & 0.76 & & -0.76 \\
\hline Germany & 0.034 & & -0.022 & 0.41 & & -0.41 & 0.205 & & -0.134 & 1.40 & & -1.40 \\
\hline & -0.008 & & 0.007 & -0.07 & & 0.07 & 0.052 & & -0.047 & 0.42 & & -0.42 \\
\hline Hungary & 0.058 & & -0.309 & 1.61 & & -1.61 & 0.009 & & -0.048 & 0.19 & & -0.19 \\
\hline Iceland & & 0.061 & 0.091 & & -0.14 & 0.14 & & -0.111 & 0.043 & & -0.53 & 0.53 \\
\hline India & -0.051 & & 0.273 & -1.27 & & 1.27 & -0.084 & & 0.451 & -1.37 & & 1.37 \\
\hline Ireland & & 0.042 & -0.080 & & 0.73 & -0.73 & & -0.063 & 0.122 & & -0.66 & 0.66 \\
\hline & 0.130 & & -0.040 & 1.01 & & -1.01 & 0.461 & & -0.143 & $2.43^{\star \star}$ & & $-2.43^{\star \star}$ \\
\hline Italy & 0.136 & 0.183 & -0.416 & 0.88 & $2.47^{\star \star}$ & $-3.95^{\star \star}$ & -0.103 & 0.243 & -0.346 & -0.43 & $2.11^{\star \star}$ & -1.89 \\
\hline & 0.121 & & 0.109 & 0.13 & & -0.13 & 0.112 & & 0.085 & 0.06 & & -0.06 \\
\hline Luxembourg & & -0.024 & 0.155 & & -0.70 & 0.70 & & -0.004 & 0.026 & & -0.09 & 0.09 \\
\hline Mexico & -0.053 & 0.175 & -0.227 & -0.29 & 1.82 & -1.69 & 0.053 & 0.167 & -0.286 & 0.24 & 1.42 & -1.77 \\
\hline Netherlands & 0.067 & & -0.031 & 0.47 & & -0.47 & 0.290 & & -0.134 & $2.09^{\star \star}$ & & $-2.09^{\star \star}$ \\
\hline New Zealand & 0.029 & & -0.021 & 0.40 & & -0.40 & -0.062 & & 0.045 & -0.48 & & 0.48 \\
\hline Norway & -0.088 & & 0.151 & -0.94 & & 0.94 & -0.084 & & 0.144 & -1.38 & & 1.38 \\
\hline Pakistan & -0.202 & & 0.263 & -0.89 & & 0.89 & -0.018 & & -0.125 & 0.52 & & -0.52 \\
\hline Philippines & & 0.094 & -0.044 & & 0.39 & -0.39 & & & 0.111 & & -0.16 & 0.16 \\
\hline Poland & 0.091 & -1.835 & 0.159 & 1.64 & $-5.11^{\star \star \star}$ & 0.62 & 0.133 & -0.495 & -0.501 & 1.85 & -0.81 & -1.54 \\
\hline Portugal & 0.099 & -0.279 & -0.076 & 0.89 & -0.69 & -0.52 & -0.129 & -0.051 & 0.183 & -0.97 & -0.11 & 1.06 \\
\hline Romania & -0.125 & 0.155 & 0.233 & -0.98 & 0.60 & 0.63 & 0.052 & -0.006 & 0.231 & -0.14 & -0.37 & 0.66 \\
\hline Russia & & -0.203 & 0.259 & & -1.33 & 1.33 & & -0.525 & 0.436 & & $-2.50^{\star \star}$ & $2.50^{\star \star *}$ \\
\hline South Africa & -0.127 & & 0.114 & $-2.10^{\star *}$ & & $2.10^{\text {** }}$ & -0.056 & & 0.050 & -0.44 & & 0.44 \\
\hline South Korea & & 0.190 & -0.088 & & 1.57 & -1.57 & & 0.206 & -0.095 & & 0.93 & -0.93 \\
\hline
\end{tabular}


TABLE 1 (continued)

Univariate Analysis for the Relation between Policy and Innovation

\begin{tabular}{|c|c|c|c|c|c|c|c|c|c|c|c|c|}
\hline 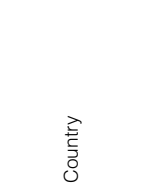 & $\stackrel{\square}{ \pm}$ & 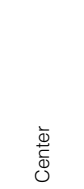 & 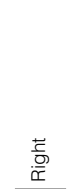 & 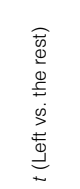 & 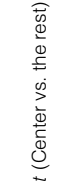 & 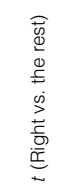 & $\stackrel{ \pm}{ \pm}$ & 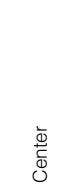 & $\begin{array}{l}\frac{\vec{\tau}}{0} \\
\frac{0}{\tilde{I}}\end{array}$ & 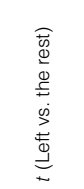 & 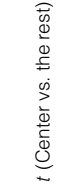 & 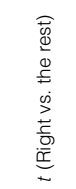 \\
\hline & \multicolumn{6}{|c|}{ Panel G. EXPLORATION (continued) } & \multicolumn{6}{|c|}{ Panel H. EXPLOITATION (continued) } \\
\hline Spain & 0.057 & -0.025 & -0.123 & 0.83 & -0.11 & -0.84 & -0.121 & 0.248 & 0.192 & -1.21 & 0.70 & 0.77 \\
\hline Sweden & 0.080 & 0.252 & -0.353 & 1.35 & 1.26 & $-2.71^{\star \star}$ & 0.095 & 0.179 & -0.354 & 1.49 & 0.81 & $-2.47^{\text {** }}$ \\
\hline Switzerland & 0.067 & -0.152 & 0.234 & $-2.26^{\star \star}$ & -1.69 & $3.14^{\star \star}$ & 0.147 & 1.072 & 0.068 & 0.02 & 5.84 & -1.52 \\
\hline Turkey & 0.234 & -0.326 & 0.023 & 0.87 & -1.14 & 0.14 & 0.062 & -0.133 & 0.089 & 0.06 & -0.74 & 0.51 \\
\hline Ukraine & 0.271 & -0.101 & & 1.40 & -1.40 & & 0.371 & 0.024 & & 0.61 & -0.61 & \\
\hline United Kingdom & -0.084 & & 0.076 & -1.29 & & 1.29 & -0.225 & & 0.203 & $-2.23^{\star \star}$ & & $2.23^{\star \star}$ \\
\hline United States & -0.141 & & 0.102 & -1.74 & & 1.74 & -0.215 & & 0.157 & -1.01 & & 1.01 \\
\hline Uruguay & 0.208 & & 0.097 & 0.35 & & -0.35 & -0.069 & & 0.072 & -0.98 & & 0.98 \\
\hline Venezuela & 0.091 & & 0.178 & -0.53 & & 0.53 & 0.026 & & 0.286 & -0.61 & & 0.61 \\
\hline
\end{tabular}

particular policy dominating or being dominated by other policies with respect to innovation. At the aggregate level shown in the row "All," we do not find any policy (left, center, or right) associated with significantly higher or lower innovation than other policies with one exception: CITATION_BOTTOM_25_PCT ${ }_{j, i, t+1}$ is significantly lower in the right policy. We conclude there is no strong evidence for policy being significantly related to innovation levels in the average country, although we do find that policies matter in a very few specific countries. Following equation (5), this finding resolves a key empirical issue: Investment in innovation under different policies does not differ much because the innovation productivities under the 2 parties are similar for the average country.

\section{B. Multivariate Regression Analysis for Policy, Policy Uncertainty, and Innovation}

For a formal analysis of the effect of policy and policy uncertainty on innovation, we use industry-level innovation variables because some countries may be more diversified among different technologies, whereas others may be more concentrated in some specific technologies. For these latter countries, the predominance of certain industries could affect our analysis of the effect of policy and policy uncertainty on innovation in two ways. First, countries and politicians may use R\&D tax credits and government resources to support some selected high-tech industries. In turn, the innovation level of those countries could be driven by 1 or 2 industries that are particularly sensitive to political stability. Second, technological innovation is subject to country and industry endowments because some industries are particularly well developed in certain countries because of natural resources and geographic reasons (e.g., Ellison and Glaeser (1997)). These industries, then, are naturally less subject to government instability. Because of these issues, we must explore the effect of policy and policy uncertainty on innovation in a multivariate regression framework, using a countryindustry-year panel and controlling for country-industry fixed effects. We thus estimate the following panel regression model to examine the effect of policy and policy uncertainty on innovation: 
(8) INNOVATION $_{j, i, t+1}=\alpha+\beta_{1}$ ELECTION $_{i, t}+\beta_{2}$ POLICY $_{i, t}+\beta_{3} \mathrm{GDP}_{i, t}$ $+\beta_{4}$ INNOVATION $_{j, i, t}+\gamma_{j, i}$ COUNTRY_INDUSTRY $_{j, i}+\rho_{t}$ YEAR $_{t}+e_{j, i, t}$,

where the dependent variable, INNOVATION ${ }_{j, i, t+1}$, is the natural logarithmic value of 1 plus one of our innovation measures in industry $j$ in country $i$ in year $t+1$ : PATENT $_{j, i, t+1}$, CITATION $_{j, i, t+1}$, ORIGINALITY $_{j, i, t+1}$, CITATION_TOP $_{-}$ 25_PCT ${ }_{j, i, t+1}$, CITATION_BOTTOM_25_PCT ${ }_{j, i, t+1}$, CITATION_STD_DEV $V_{j, i, t+1}$, EXPLORATION $_{j, i, t+1}$, and EXPLOITATION E $_{j, i, t+1}$. We use the logarithmic scale to mitigate skewness. Note that the innovation level is measured a year later because in our theoretical model, patent filings (i.e., the success of the idea) lag investment in innovation by 1 period. That also happens in practice (see footnote 14). The fixed effects for country-industry pair control for all time-invariant determinants of innovation for each industry in each country. The year fixed effects control for all global trends in innovation.

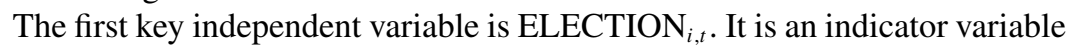
that equals 1 if there is at least 1 primary election in country $i$ in year $t$, and 0 otherwise. This variable measures policy uncertainty. The sign and magnitude of the estimate of $\beta_{1}$ suggest how and to what extent policy uncertainty influences country-industry-level innovation.

The second key independent variable is $\mathrm{POLICY}_{i, t}$, which is either $\mathrm{LEFT}_{i, t}$ or $\mathrm{RIGHT}_{i, t} \cdot \mathrm{RIGHT}_{i, t}$ is an indicator variable that equals 1 if country $i$ 's government is right wing in year $t$, and 0 otherwise, and $\mathrm{LEFT}_{i, t}$ is an indicator variable that equals 1 if country $i$ 's government is left wing in year $t$, and 0 otherwise. These variables measure policy. This research design allows us to examine whether the right is better than the rest, and then whether the left is better than the rest. Therefore, the sign and magnitude of the estimate of $\beta_{2}$ suggest whether one economic policy is significantly more effective in promoting innovation than others.

The other control variables are as follows. $\mathrm{GDP}_{i, t}$ denotes the growth of GDP of country $i$ in year $t$. GDP growth controls for the effect of aggregate economic conditions on innovation. INNOVATION ${ }_{j, i, t}$ denotes lagged innovation variables, which control for the persistence of industry-level technological progress. This attenuates the reverse causality issue, which could occur if $\operatorname{INNOVATION}_{j, i, t}$ is persistent and directly affects the timing of national elections in year $t$.

Finally, we follow Julio and Yook (2012) and include country-industry fixed effects (COUNTRY_INDUSTRY $\left.{ }_{j, i}\right)$ and year fixed effects $\left(\right.$ YEAR $\left._{t}\right)$. Country-industry fixed effects capture any characteristics associated with specific industries in certain countries, and address concerns that our analysis of policy uncertainty on innovation is biased by particular industries or countries. Year fixed effects control for any time-varying common component in either global business cycles or time-series patterns in U.S. patent grants. Also, year fixed effects help to correct bias associated with application lags and vintage issues, if any. We cluster standard errors by both country-industry and year to accommodate time-series errors in the same industry in the same country, as well as cross-correlational errors in the same year. ${ }^{18}$

${ }^{18}$ We obtain similar empirical results when we cluster standard errors by country or by country and year. 
We use 8 measures of innovation as the dependent variable: patent, citation, originality, influential patents with citations in the top $25 \%$, marginal patents with citations in the bottom $25 \%$, the standard deviation of citations, exploitation patents (patents that have at least 1 self-cite), and exploration patents (patents that have no self-cites). We then use 4 specifications for each of these 8 measures. The first specification has ELECTION ELt $_{i, t}$ and INNOVATION $_{j, i, t}$ as independent variables. The second specification adds $\mathrm{GDP}_{i, t}$. The third specification adds RIGHT $_{i, t}$. The fourth specification removes RIGHT $_{i, t}$ and adds LEFT $_{i, t}$. All 4 specifications control for country-industry fixed effects and year fixed effects. Because the qualitative results are similar for all 4 specifications, Table 2 presents only the results of the fourth specification for brevity's sake.

\section{The Effect on Quantity and Quality of Innovation}

We notice from Table 2 that the coefficient estimate of ELECTION ${ }_{i, t}$ is negative and significant in the first 3 measures of innovation, which suggests that innovation, however measured (by patents, citations, or originality), declines on average 1 year after national elections in all 43 countries. Such a drop in innovation ranges from $1.8 \%$ to $3.5 \%$ following an election. We also find that innovation variables are very persistent in time as the coefficient estimate of INNOVATION $_{j, i, t}$ falls in the range between $67 \%$ and $85 \%$ with strong statistical significance. Conversely, we do not find the coefficient estimate of $\mathrm{GDP}_{i, t}$ to be statistically significant, suggesting that innovation level cannot be explained by economic growth.

Interestingly, the coefficient estimate of POLICY P $_{i, t}$ (where policy is $\mathrm{LEFT}_{i, t}$ ) is not statistically different from 0 for patents, citations, or originality, suggesting that left parties are neither better nor worse than other parties with respect to these dimensions of innovation. Policy does not affect any other dimensions of innovation, as seen in the insignificant coefficients on policy for the other 5 measures of innovation in Table 2. ${ }^{19}$

\section{The Effect on Influential Innovations}

We do notice that the negative effect of elections is greater for influential patents with citations in the top $25 \%$ compared to all patents. Specifically, we see a $2.3 \%$ drop here compared to the $1.8 \%$ drop in all patents. However, we do not find a significant effect of elections on marginal patents with citations in the bottom $25 \%$. These findings suggest that the association between elections and innovation is stronger among influential patents, which confirms the adverse effect of policy uncertainty on innovation quality. Elections also decrease the standard deviation of citations, which suggests that elections suppress risk taking in innovation. Consistent with the contrast between influential patents and marginal patents, we also find that elections discourage exploratory patents but have no effect on exploitative patents.

Overall, the results presented in Table 2 support the hypothesis that policy uncertainty (as measured by elections) adversely affects innovation activities. Firms under policy uncertainty tend to generate fewer and less influential

\footnotetext{
${ }^{19}$ Although not shown in Table 2, we do find that the coefficient estimate of POLICY (where $_{i, t}$ policy is $\mathrm{RIGHT}_{i, t}$ ) is not statistically different from 0 for patents, but is significant and negative when it comes to citation and originality. It could be that the parties of the right, being conservative, encourage true and tested technologies, but without further evidence, this remains just a conjecture.
} 
TABLE 2

Regression Analysis for the Relation between Policy, Policy Uncertainty, and Innovation

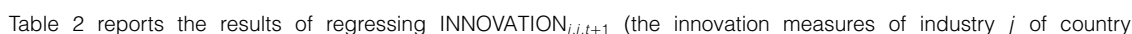
$i$ in year $t+1$ ) on ELECTION $i, t$ (an indicator variable that equals 1 if there is at least 1 primary election in country $i$ in year $t$, and 0 otherwise), LEFT $T_{i, t}$ (an indicator variable that equals 1 if country i's government is left wing in year $t$, and 0 otherwise), GDP (t, (the growth of GDP of country $i$ in year $t$ ), current innovation INNOVATION ${ }_{i, i, t}$, country-industry fixed effects (FEs), and year FEs. Our innovation measure INNOVATION

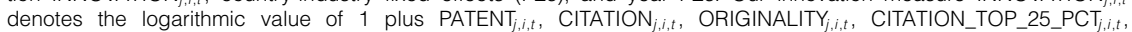
CITATION_BOTTOM_25_PCT ${ }_{i, i, t}$, CITATION_STD_DEV ${ }_{i, i, t}$, EXPLORATION $_{i, i, t}$, and EXPLOITATION ${ }_{i, i, t}$. We include all 43 countries in our sample. Numbers reported in parentheses are 2-way clustered standard errors by country-industries and by years. The sample year $t$ is from 1976 to $2010 .{ }^{*},{ }^{* *}$, and ${ }^{* *}$ indicate statistical significance at the $10 \%, 5 \%$, and $1 \%$ levels, respectively.

\begin{tabular}{|c|c|c|c|c|c|c|c|c|}
\hline 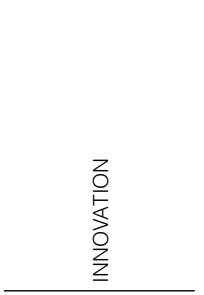 & 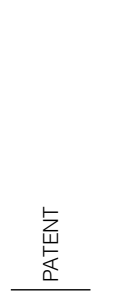 & $\begin{array}{l}Z \\
\stackrel{Z}{E} \\
\stackrel{\mathbb{E}}{\mathrm{E}} \\
\mathrm{U}\end{array}$ & 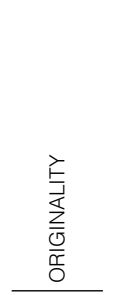 & 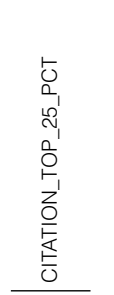 & 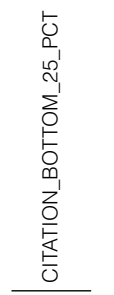 & 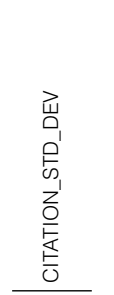 & 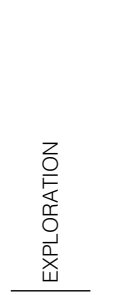 & 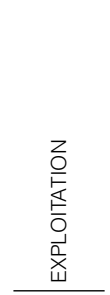 \\
\hline ELECTION $_{i, t}$ & $\begin{array}{l}-0.018^{* *} \\
(-2.511)\end{array}$ & $\begin{array}{l}-0.035^{\star} \\
(-1.718)\end{array}$ & $\begin{array}{l}-0.018^{* *} \\
(-2.559)\end{array}$ & $\begin{array}{l}-0.023^{* *} \\
(-2.367)\end{array}$ & $\begin{array}{c}-0.005 \\
(-0.638)\end{array}$ & $\begin{array}{c}-0.032^{\star} \\
(-1.822)\end{array}$ & $\begin{array}{l}-0.013^{* *} \\
(-2.228)\end{array}$ & $\begin{array}{l}-0.007 \\
(-0.583)\end{array}$ \\
\hline INNOVATION $_{j, i, t}$ & $\begin{array}{c}0.835^{\star \star \star} \\
(39.055)\end{array}$ & $\begin{array}{c}0.666^{\star \star \star} \\
(14.162)\end{array}$ & $\begin{array}{c}0.853^{* * *} \\
(52.847)\end{array}$ & $\begin{array}{c}0.784^{\star * \star} \\
(24.021)\end{array}$ & $\begin{array}{c}0.820^{\star \star \star} \\
(33.790)\end{array}$ & $\begin{array}{c}0.651^{\text {}} \\
(13.537)\end{array}$ & $\begin{array}{c}0.820^{\star \star \star} \\
(34.713)\end{array}$ & $\begin{array}{c}0.914^{\star \star \star} \\
(15.917)\end{array}$ \\
\hline $\mathrm{GDP}_{i, t}$ & $\begin{array}{c}0.000 \\
(-0.275)\end{array}$ & $\begin{array}{c}0.001 \\
(0.335)\end{array}$ & $\begin{array}{c}0.002 \\
(1.473)\end{array}$ & $\begin{array}{c}-0.002 \\
(-1.177)\end{array}$ & $\begin{array}{c}-0.002 \\
(-0.957)\end{array}$ & $\begin{array}{c}0.007^{\star} \\
(1.817)\end{array}$ & $\begin{array}{l}-0.001 \\
(-0.895)\end{array}$ & 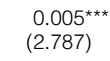 \\
\hline $\mathrm{LEFT}_{i, t}$ & $\begin{array}{c}0.006 \\
(0.626)\end{array}$ & $\begin{array}{c}0.033 \\
(1.627)\end{array}$ & $\begin{array}{c}0.008 \\
(1.025)\end{array}$ & $\begin{array}{c}-0.008 \\
(-0.948)\end{array}$ & $\begin{array}{c}0.007 \\
(0.724)\end{array}$ & $\begin{array}{c}-0.009 \\
(-0.480)\end{array}$ & $\begin{array}{c}0.004 \\
(0.451)\end{array}$ & $\begin{array}{c}0.016 \\
(1.187)\end{array}$ \\
\hline $\begin{array}{l}\text { No. of obs. } \\
R^{2}\end{array}$ & $\begin{array}{r}25,060 \\
0.698\end{array}$ & $\begin{array}{r}25,060 \\
0.419\end{array}$ & $\begin{array}{r}25,060 \\
0.777\end{array}$ & $\begin{array}{r}25,060 \\
0.601\end{array}$ & $\begin{array}{r}25,060 \\
0.671\end{array}$ & $\begin{array}{r}20,240 \\
0.406\end{array}$ & $\begin{array}{r}25,060 \\
0.675\end{array}$ & $\begin{array}{r}25,060 \\
0.684\end{array}$ \\
\hline $\begin{array}{l}\text { Country-industry FEs } \\
\text { Year FEs }\end{array}$ & $\begin{array}{l}\text { Yes } \\
\text { Yes }\end{array}$ & $\begin{array}{l}\text { Yes } \\
\text { Yes }\end{array}$ & $\begin{array}{l}\text { Yes } \\
\text { Yes }\end{array}$ & $\begin{array}{l}\text { Yes } \\
\text { Yes }\end{array}$ & $\begin{array}{l}\text { Yes } \\
\text { Yes }\end{array}$ & $\begin{array}{l}\text { Yes } \\
\text { Yes }\end{array}$ & $\begin{array}{l}\text { Yes } \\
\text { Yes }\end{array}$ & $\begin{array}{l}\text { Yes } \\
\text { Yes }\end{array}$ \\
\hline
\end{tabular}

inventions and engage in less original projects. Firms under policy uncertainty also undertake less risky innovations, resulting in fewer influential and exploratory patents. Bloom et al. (2007), Julio and Yook (2012), (2016), and Gulen and Ion (2016) also find a negative effect of policy uncertainty on the quantity of investment. In our article, we document the negative effect of policy uncertainty not only on the quantity and quality of innovation, but also on incentives to undertake risky and exploratory innovation.

\section{Policy Uncertainty and Innovation: Close Presidential Elections}

To further strengthen the causal relation between policy uncertainty and innovation, we consider close presidential elections as an alternative event of interest. Presidential elections are more exogenous than parliamentary elections. According to Julio and Yook (2012), all presidential elections in countries in our sample are held regularly and can thus be considered to have exogenous timing. In contrast, parliamentary elections may be subject to endogenous timing (e.g., Heckelman and Berument (1998)). The second advantage of using close presidential elections is that they are better proxies for policy uncertainty because election outcomes are unpredictable (e.g., Snowberg, Wolfers, and Zitzewitz (2007)). Therefore, a strong relation between close presidential elections and subsequent patent-based variables imply a stronger causal effect of policy uncertainty on innovation activities. 
Because the DPI does not report the percentages of votes received by runnerups in presidential elections that are necessary for us to define close elections, we resort to the Election Results Archive (ERA), a collection of electronic files that contain data on global election results and are maintained by the Center on Democratic Performance at Binghamton University. The ERA also reports the percentages of votes received by all presidential candidates, allowing us to construct our variable of interest (CLOSE_ELECTION ${ }_{i, t}$ ) for country $i$ in year $t$. We code this variable as 1 if a presidential election occurs in which the margin between the winner's vote percentage and the runner-up's is within the 5\% range in country $i$ in year $t$, and 0 otherwise (Akey (2015), Brogaard, Denes, and Duchin (2016)). Based on this definition, we obtain 11 close presidential election events: Argentina in 2003; Colombia in 1978 and 1994; Philippines in 1992 and 2004; Poland in 1995; Uruguay in 1994; the United States in 1976, 2000, and 2004; and Venezuela in 1978.

We then estimate equation (8) while replacing ELECTION $_{i, t}$ with CLOSE_ELECTION $_{i, t}$, which is an indicator variable equal to 1 if there is 1 close presidential election in country $i$ in year $t$, and 0 otherwise. The other variables and the interpretations of their coefficient estimates remain the same as in equation (8). Table 3 reports the results for close presidential elections. As in Table 2, we report the results for patents, citations, originality, influential patents (top $25 \%$ in citations), marginal patents (bottom $25 \%$ in citations), standard deviation of citations, exploratory patents, and exploitative patents.

We still find that patents and citations drop a year after close presidential elections. There seems to be no effect on originality. The drop in patents (about $4.6 \%$ ) and the drop in citations (about 15\%) after close presidential elections are much larger than the drops we observe after the average election in Table 2. This finding supports the notion that a higher level of policy uncertainty captured by close elections leads to a greater adverse effect on innovation activities.

Although there seems to be no effect of close elections on the right tail or the left tail of the citation distribution, we find that the standard deviation of citations significantly drops right after close elections. Moreover, we uncover an interesting result: Close elections discourage exploratory patents but have no effect on exploitative patents. These findings collectively suggest that when policy uncertainty rises in close elections, firms engage in lower levels of intangible investments, pursue less influential inventions, and take less risk and less exploratory approaches in their innovation activities. These results help strengthen the causality that runs from policy uncertainty to innovation.

Meanwhile, we notice in Table 3 that policies of the left parties do not affect any measures of innovation. Again, as with Table 2, we do notice, but do not report, that the policies of the right parties curb citation and originality, but do not affect the level of influential patents, marginal patents, standard deviation in citations, exploration, and exploitation. Thus, the results on policy are the same as those seen in Table 2.

\section{Subsample Analysis Based on Ethnic Fractionalization}

We next explore how ethnic fractionalization (i.e., how divided and diverse a country is in terms of ethnic composition) alters the effect of policy uncertainty on innovation activities to further establish the causal link. We postulate 


\section{TABLE 3}

Regression Analysis for the Relation between Policy, Policy Uncertainty, and Innovation: Close Presidential Elections

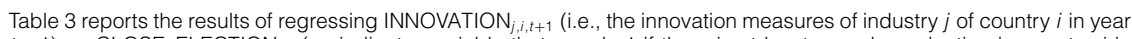
$t+1$ ) on CLOSE ELECTION ${ }_{i, t}$ (an indicator variable that equals 1 if there is at least one close election in country $i$ in year $t$, and 0 otherwise), LEFT $i, t$ (an indicator variable that equals 1 if country $i$ 's government is left wing in year $t$, and 0

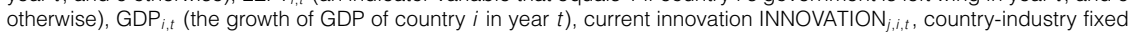
effects (FEs), and year FEs. INNOVATION ORIGINALITY ${ }_{j, i, t}, \quad$ CITATION_TOP_25_PCT EXPLORATION $_{i, i, t}$, and EXPLOITATION ${ }_{i, j, t}$. We include all 43 countries in our sample. Numbers reported in parentheses are 2-way clustered standard errors by country-industries and by years. The sample year $t$ is from 1976 to 2010. ${ }^{*},{ }^{* *}$, and ${ }^{* * *}$ indicate statistical significance at the $10 \%, 5 \%$, and $1 \%$ levels, respectively.

\begin{tabular}{|c|c|c|c|c|c|c|c|c|}
\hline 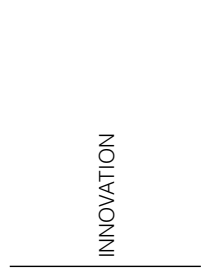 & 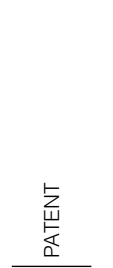 & $\begin{array}{l}\frac{Z}{O} \\
\frac{1}{E} \\
\frac{\mathbb{E}}{0}\end{array}$ & 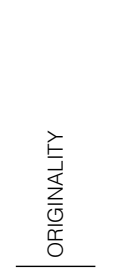 & 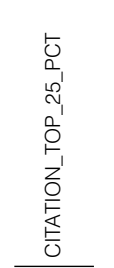 & 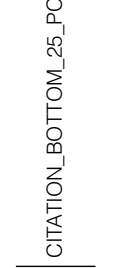 & 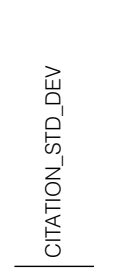 & 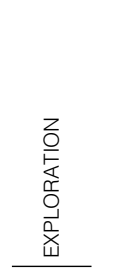 & $\begin{array}{l}z \\
\stackrel{z}{0} \\
\stackrel{\underline{E}}{E} \\
\overline{0} \\
\overrightarrow{0} \\
\text { 离 }\end{array}$ \\
\hline ELECTION $_{i, t}$ & $\begin{array}{l}-0.046^{*} \\
(-1.805)\end{array}$ & $\begin{array}{l}-0.151^{*} \\
(-1.928)\end{array}$ & $\begin{array}{l}-0.018 \\
(-0.853)\end{array}$ & $\begin{array}{c}0.013 \\
(0.552)\end{array}$ & $\begin{array}{l}-0.033 \\
(-0.908)\end{array}$ & $\begin{array}{l}-0.097^{\star *} \\
(-2.088)\end{array}$ & $\begin{array}{l}-0.044^{*} \\
(-1.730)\end{array}$ & $\begin{array}{c}0.047 \\
(0.752)\end{array}$ \\
\hline INNOVATION ${ }_{j, i, t}$ & $\begin{array}{l}0.836^{* * *} \\
(39.012)\end{array}$ & $\begin{array}{l}0.666^{\star \star \star} \\
(14.140)\end{array}$ & $\begin{array}{l}0.853^{\text {*** }} \\
(52.672)\end{array}$ & $\begin{array}{l}0.784^{\text {*** }} \\
(24.018)\end{array}$ & $\begin{array}{l}0.820^{\text {*** }} \\
(33.813)\end{array}$ & $\begin{array}{l}0.650^{\star \star \star} \\
(13.411)\end{array}$ & $\begin{array}{l}0.821^{\text {*** }} \\
(34.691)\end{array}$ & $\begin{array}{l}0.914^{\star \star \star} \\
(15.937)\end{array}$ \\
\hline $\mathrm{GDP}_{i, t}$ & $\begin{array}{c}0.000 \\
(-0.271)\end{array}$ & $\begin{array}{c}0.002 \\
(0.359)\end{array}$ & $\begin{array}{c}0.001 \\
(1.373)\end{array}$ & $\begin{array}{l}-0.002 \\
(-1.239)\end{array}$ & $\begin{array}{l}-0.002 \\
(-0.939)\end{array}$ & $\begin{array}{r}0.007^{\star} \\
(1.907)\end{array}$ & $\begin{array}{l}-0.001 \\
(-0.877)\end{array}$ & $\begin{array}{l}0.005^{\text {} \star \star \star ~} \\
(2.754)\end{array}$ \\
\hline $\operatorname{LEFT}_{i, t}$ & $\begin{array}{l}0.006 \\
(0.619)\end{array}$ & $\begin{array}{c}0.032 \\
(1.632)\end{array}$ & $\begin{array}{c}0.008 \\
(1.034)\end{array}$ & $\begin{array}{l}-0.008 \\
(-0.952)\end{array}$ & $\begin{array}{c}0.007 \\
(0.714)\end{array}$ & $\begin{array}{l}-0.009 \\
(-0.436)\end{array}$ & $\begin{array}{l}0.004 \\
(0.441)\end{array}$ & $\begin{array}{c}0.016 \\
(1.197)\end{array}$ \\
\hline $\begin{array}{l}\text { No. of obs. } \\
R^{2}\end{array}$ & $\begin{array}{r}25,060 \\
0.698\end{array}$ & $\begin{array}{r}25,060 \\
0.419\end{array}$ & $\begin{array}{r}25,060 \\
0.776\end{array}$ & $\begin{array}{r}25,060 \\
0.600\end{array}$ & $\begin{array}{r}25,060 \\
0.671\end{array}$ & $\begin{array}{r}20,240 \\
0.405\end{array}$ & $\begin{array}{r}25,060 \\
0.675\end{array}$ & $\begin{array}{r}25,060 \\
0.684\end{array}$ \\
\hline $\begin{array}{l}\text { Country-industry FEs } \\
\text { Year FEs }\end{array}$ & $\begin{array}{l}\text { Yes } \\
\text { Yes }\end{array}$ & $\begin{array}{l}\text { Yes } \\
\text { Yes }\end{array}$ & $\begin{array}{l}\text { Yes } \\
\text { Yes }\end{array}$ & $\begin{array}{l}\text { Yes } \\
\text { Yes }\end{array}$ & $\begin{array}{l}\text { Yes } \\
\text { Yes }\end{array}$ & $\begin{array}{l}\text { Yes } \\
\text { Yes }\end{array}$ & $\begin{array}{l}\text { Yes } \\
\text { Yes }\end{array}$ & $\begin{array}{l}\text { Yes } \\
\text { Yes }\end{array}$ \\
\hline
\end{tabular}

that ethnic fractionalization amplifies the adverse effect of policy uncertainty on innovation because it has the following features. ${ }^{20}$ First, ethnic division likely increases political polarization and thereby impedes the formation of social consensus on economic policies (Easterly and Levine (1997)). Second, Knack and Keefer (1997) find that ethnically homogeneous countries possess greater "social capital" (i.e., trust and civic norms). Third, Connor (1994) suggests that the real source of civil violence and rebellion is often ethnic nationalism. Finally, La Porta et al. (1999) and Radro i Miquel (2007) argue that in ethnically heterogeneous societies, it is common for the in-power ethnic group to adopt discriminative policies to maintain political dominance. Therefore, when a society is full of disagreement and distrust, lacks social norms and fairness, and is subject to potential civil

\footnotetext{
${ }^{20}$ It is common in the economics and political science literature to treat ethnic distribution as an exogenous variable with respect to political dynamics and economic growth. According to Alesina et al. ((2003), p. 160),
}

Ethnic fractionalization indices are generally taken as exogenous in cross-country regressions, based on the fact that group shares are sufficiently stable that changes only have a minor impact on fractionalization measures. This seems a reasonable assumption at the 30 year horizon of the typical cross-country regression, even though this assumption may be less tenable for a much longer horizon. 
violence, it is more likely for any political election to result in a greater disruption among all socioeconomic groups.

To empirically test our conjecture, we collect the ethnic distribution of all our countries from the CIA World Factbook and follow the literature to construct 2 ethnic concentration proxies. ${ }^{21}$ The first proxy is the share of the largest ethnic group (e.g., Keefer and Knack (2002)), and the second proxy is the Herfindahl index based on the shares of different ethnic groups (e.g., Alesina et al. (2003)). It is clear that these two indices are negatively related to ethnic fractionalization status. We split all sample countries into high and low groups when their largest ethnic groups' shares are above the 70th percentile (below the 30th percentile) in each year. We also split all sample countries into high and low groups when their ethnicity-based Herfindahl indexes are above the 70th percentile (below the 30th percentile) in each year.

Our strategy is to conduct subsample regressions and to compare the coefficients on the variable of interest across the 2 subsamples. Specifically, we conduct the regression of equation (8) for the high and low subsamples, and then examine the coefficient on ELECTION ${ }_{i, t}$ in the low-ethnic-concentration group (i.e., high-ethnic-fractionalization group) and in the high-ethnic-concentration group (i.e., low-ethnic-fractionalization group), and then again examine the coefficient on ELECTION ${ }_{i, t}$ in the low-Herfindahl-index country (i.e., high-ethnicfractionalization group) and in the high-Herfindahl-index country (i.e., lowethnic-fractionalization group).$^{22}$

Table 4 presents the results for all 43 countries when we split all sample countries into high (low) groups when their largest ethnic groups' shares are above (below) the 70th (30th) percentile in each year in Panel A (B). Also, Table 5 presents the results for all 43 countries when we split all sample countries into high (low) groups when their ethnicity-based Herfindahl indexes are above (below) the 70th (30th) percentile in each year in Panel A (B). In Tables 4 and 5, we find that the coefficient on ELECTION $_{i, t}$ in a high-ethnic-fractionalization country is negative and significant (except in CITATION_BOTTOM_25_PCT, CITATION_STD_DEV, and EXPLOITATION, where they are all insignificant), whereas the coefficient on ELECTION ELt $_{i, t}$ in a low-ethnic-fractionalization country is insignificant everywhere. Tables 4 and 5 thus suggest that innovation drops after an election more in an ethnically heterogeneous country than in an ethnically homogeneous country.

Overall, our subsample regressions based on ethnic fragmentation suggest that when policy uncertainty occurs, the heterogeneity in population seems to strengthen the negative effect of policy uncertainty. This finding further strengthens the causal interpretation for policy uncertainty on innovation. If both elections and innovation activities are driven by an omitted variable, the influence of this omitted variable should be consistent with the observed cross-sectional variation in ethnic fractionalization. It is, however, difficult to think of an omitted variable that affects both policy uncertainty and innova-

\footnotetext{
${ }^{21}$ We are able to collect the data for the following years: 1982, 1984-1987, and 1989-2006. We fill in the missing data (1976-1981 and 1983) using the 1982 data.

${ }^{22}$ For brevity's sake, we do not include POLICY and GDP in the subsample regressions. Nevertheless, we obtain consistent results when we include these variables in regressions.
} 
TABLE 4

Regression Analysis for the Relation between Policy, Policy Uncertainty, and Innovation: Subsample Analysis for Ethnic Fractionalization (largest ethnic group)

Table 4 reports the subsample results of regressing INNOVATION ${ }_{j, i, t+1}$ (i.e., innovation measures of industry $j$ of country

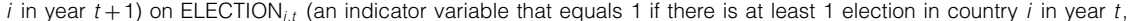
and 0 otherwise), current innovation INNOVATION ${ }_{i, i, t}$, country-industry fixed effects (FEs), and year FEs in the low or high subsample by ethnic concentration. We split all sample countries into high (low) groups when their largest ethnic groups' shares are above (below) the 70th (30th) percentile in each year. INNOVATION value of 1 plus PATENT $T_{j, i}$, , CITATION ${ }_{j, i, t}$, ORIGINALITY $Y_{j, i}$, CITATION_TOP_25_PCT $_{j, i, t}$, CITATION_BOTTOM_25_PCT $_{j, i, t}$, CITATION_STD_DEV $V_{i, j,}$, EXPLORATION ${ }_{i, t,}$, and EXPLOITATION EX $_{i, t}$. Numbers reported in parentheses are 2-way clustered standard errors by country-industries and by years. The sample year $t$ is from 1976 to 2010. *, **, and *** indicate statistical significance at the $10 \%, 5 \%$, and $1 \%$ levels, respectively.

\begin{tabular}{|c|c|c|c|c|c|c|c|c|}
\hline 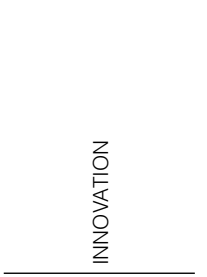 & 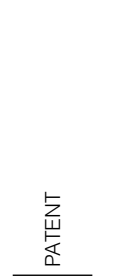 & $\begin{array}{l}\text { Zo } \\
\text { O } \\
\stackrel{\mathbb{E}}{\mathrm{E}} \\
\end{array}$ & $\begin{array}{l}\text { 竞 } \\
\frac{\mathbb{E}}{\frac{0}{0}} \\
\frac{0}{0}\end{array}$ & 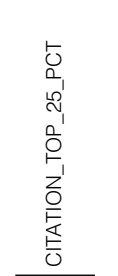 & 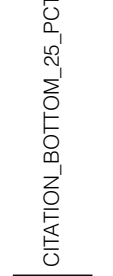 & 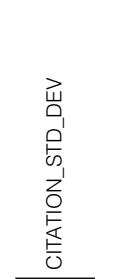 & 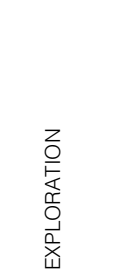 & 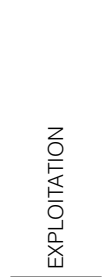 \\
\hline \multicolumn{9}{|c|}{ Panel A. The High Subsample in the Largest Ethnic Group } \\
\hline ELECTION $_{i, t}$ & $\begin{array}{l}-0.013 \\
(-0.885)\end{array}$ & $\begin{array}{l}-0.031 \\
(-0.831)\end{array}$ & $\begin{array}{l}-0.005 \\
(-0.332)\end{array}$ & $\begin{array}{l}-0.025 \\
(-1.121)\end{array}$ & $\begin{array}{c}0.018 \\
(1.206)\end{array}$ & $\begin{array}{l}-0.014 \\
(-0.388)\end{array}$ & $\begin{array}{l}-0.014 \\
(-1.006)\end{array}$ & $\begin{array}{l}0.012 \\
(0.647)\end{array}$ \\
\hline INNOVATION ${ }_{j, i, t}$ & $\begin{array}{l}0.884^{* * *} \\
(40.315)\end{array}$ & 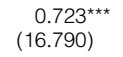 & $\begin{array}{l}0.891^{\star \star \star \star} \\
(46.074)\end{array}$ & $\begin{array}{l}0.841^{\star \star \star} \\
(22.334)\end{array}$ & $\begin{array}{c}0.866^{* \star *} \\
(31.725)\end{array}$ & $\begin{array}{l}0.651^{\star \star \star} \\
(12.965)\end{array}$ & $\begin{array}{l}0.876^{* \star \star} \\
(37.024)\end{array}$ & $\begin{array}{l}0.881^{\star \star \star} \\
(27.704)\end{array}$ \\
\hline $\begin{array}{l}\text { No. of obs. } \\
R^{2}\end{array}$ & $\begin{array}{l}8,040 \\
0.787\end{array}$ & $\begin{array}{l}8,040 \\
0.503\end{array}$ & $\begin{array}{l}8,040 \\
0.836\end{array}$ & $\begin{array}{l}8,040 \\
0.688\end{array}$ & $\begin{array}{l}8,040 \\
0.748\end{array}$ & $\begin{array}{l}5,590 \\
0.421\end{array}$ & $\begin{array}{l}8,040 \\
0.774\end{array}$ & $\begin{array}{l}8,040 \\
0.700\end{array}$ \\
\hline $\begin{array}{l}\text { Country-industry FEs } \\
\text { Year FEs }\end{array}$ & $\begin{array}{l}\text { Yes } \\
\text { Yes }\end{array}$ & $\begin{array}{l}\text { Yes } \\
\text { Yes }\end{array}$ & $\begin{array}{l}\text { Yes } \\
\text { Yes }\end{array}$ & $\begin{array}{l}\text { Yes } \\
\text { Yes }\end{array}$ & $\begin{array}{l}\text { Yes } \\
\text { Yes }\end{array}$ & $\begin{array}{l}\text { Yes } \\
\text { Yes }\end{array}$ & $\begin{array}{l}\text { Yes } \\
\text { Yes }\end{array}$ & $\begin{array}{l}\text { Yes } \\
\text { Yes }\end{array}$ \\
\hline \multicolumn{9}{|c|}{ Panel B. The Low Subsample in the Largest Ethnic Group } \\
\hline ELECTION $_{i, t}$ & $\begin{array}{l}-0.037^{* *} \\
(-2.277)\end{array}$ & $\begin{array}{l}-0.089^{\star *} \\
(-2.228)\end{array}$ & $\begin{array}{l}-0.042^{\text {*** }} \\
(-3.105)\end{array}$ & $\begin{array}{l}-0.028^{\star} \\
(-1.832)\end{array}$ & $\begin{array}{l}-0.025 \\
(-1.426)\end{array}$ & $\begin{array}{l}-0.019 \\
(-0.461)\end{array}$ & $\begin{array}{l}-0.027^{*} \\
(-1.809)\end{array}$ & $\begin{array}{l}-0.029 \\
(-1.507)\end{array}$ \\
\hline INNOVATION $_{j, i, t}$ & $\begin{array}{l}0.828^{\text {** }} \\
(21.131)\end{array}$ & $\begin{array}{l}0.548^{\star \star *} \\
(8.266)\end{array}$ & $\begin{array}{c}0.838^{* * *} \\
(36.560)\end{array}$ & $\begin{array}{c}0.748^{\star \star \star} \\
(12.797)\end{array}$ & $\begin{array}{c}0.795^{* * \star} \\
(18.688)\end{array}$ & $\begin{array}{l}0.546^{\star \star \star} \\
(8.960)\end{array}$ & $\begin{array}{l}0.814^{* \star *} \\
(19.431)\end{array}$ & $\begin{array}{l}0.855^{\star \star \star} \\
(15.895)\end{array}$ \\
\hline $\begin{array}{l}\text { No. of obs. } \\
R^{2}\end{array}$ & $\begin{array}{l}6,220 \\
0.652\end{array}$ & $\begin{array}{l}6,220 \\
0.284\end{array}$ & $\begin{array}{l}6,220 \\
0.726\end{array}$ & $\begin{array}{l}6,220 \\
0.521\end{array}$ & $\begin{array}{l}6,220 \\
0.615\end{array}$ & $\begin{array}{l}4,294 \\
0.287\end{array}$ & $\begin{array}{l}6,220 \\
0.632\end{array}$ & $\begin{array}{l}6,220 \\
0.632\end{array}$ \\
\hline $\begin{array}{l}\text { Country-industry FEs } \\
\text { Year FEs }\end{array}$ & $\begin{array}{l}\text { Yes } \\
\text { Yes }\end{array}$ & $\begin{array}{l}\text { Yes } \\
\text { Yes }\end{array}$ & $\begin{array}{l}\text { Yes } \\
\text { Yes }\end{array}$ & $\begin{array}{l}\text { Yes } \\
\text { Yes }\end{array}$ & $\begin{array}{l}\text { Yes } \\
\text { Yes }\end{array}$ & $\begin{array}{l}\text { Yes } \\
\text { Yes }\end{array}$ & $\begin{array}{l}\text { Yes } \\
\text { Yes }\end{array}$ & $\begin{array}{l}\text { Yes } \\
\text { Yes }\end{array}$ \\
\hline
\end{tabular}

tion and is also correlated with ethnic fractionalization in this way. Hence, the documented effect of policy uncertainty on innovation is likely to be causal.

\section{E. Policy, Policy Uncertainty, and the Incentive to Innovate}

We next explore possible mechanisms through which policy and policy uncertainty affect innovation activities. Given that population size is stable across years, more inventors filing patents reflects a stronger incentive to innovate. We define the number of patent inventors as the number of individuals that have filed at least 1 patent in a sample country-industry-year, and then estimate the following panel regression model to examine the effect of policy and policy uncertainty on individuals' incentive to innovate:

$$
\begin{aligned}
& \operatorname{INVENTOR~}_{j, i, t+1}=\alpha+\beta_{1} \text { ELECTION }_{i, t}+\beta_{2} \text { POLICY }_{i, t} \\
& +\beta_{3} \mathrm{GDP}_{i, t}+\beta_{4} \mathrm{INVENTOR}_{j, i, t} \\
& +\gamma_{j, i} \text { COUNTRY_INDUSTRY }_{j, i} \\
& +\rho_{t} \mathrm{YEAR}_{t}+e_{j, i, t+1} \text {, }
\end{aligned}
$$




\section{TABLE 5}

Regression Analysis for the Relation between Policy, Policy Uncertainty, and Innovation: Subsample Analysis for Ethnic Fractionalization (Herfindahl index)

Table 5 reports the subsample results of regressing INNOVATION ${ }_{j, i, t+1}$ (i.e., innovation measures of industry $j$ of country $i$ in year $t+1$ ) on ELECTION ${ }_{i, t}$ (an indicator variable that equals 1 if there is at least 1 election in country $i$ in year $t$, and 0 otherwise), current innovation INNOVATION ${ }_{i, i, t}$, country-industry fixed effects (FEs), and year FEs in the low or high subsample by ethnic concentration. We split all sample countries into high (low) groups when their ethnicity-based Herfindahl indexes are above (below) the 70th (30th) percentile in each year. INNOVATION . denotes the logarithmic value of 1 plus PATENT $T_{j, i, t}$, CITATION $_{j, i, t}$, ORIGINALITY $Y_{j, i, t}$, CITATION_TOP_25_PCT $_{j, i, t}$, CITATION_BOTTOM_25_PCT $_{j, i, t}$, CITATION STD DEV $V_{i, t}$ EXPLORATION EX $_{\text {, }}$, and EXPLOITATION . Numbers reported in parentheses are 2-way clustered standard errors by country-industries and by years. The sample year $t$ is from 1976 to 2010. *, **, and *** indicate statistical significance at the $10 \%, 5 \%$, and $1 \%$ levels, respectively.

\begin{tabular}{|c|c|c|c|c|c|c|c|c|}
\hline 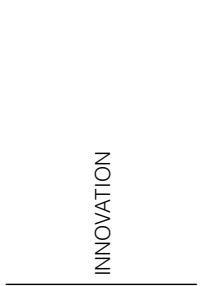 & 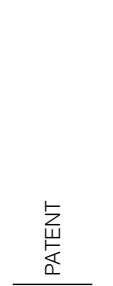 & $\begin{array}{l}\frac{Z}{O} \\
\underset{E}{E} \\
\frac{E}{U}\end{array}$ & 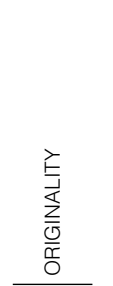 & 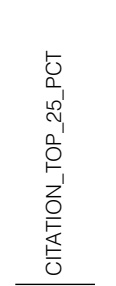 & 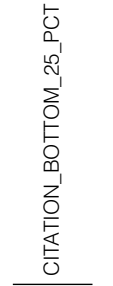 & 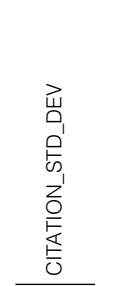 & 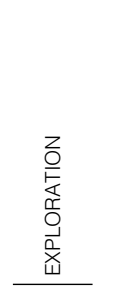 & 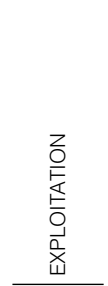 \\
\hline \multicolumn{9}{|c|}{ Panel A. The High Subsample in the Herfindahl Index } \\
\hline ELECTION $_{i, t}$ & $\begin{array}{l}-0.014 \\
(-1.184)\end{array}$ & $\begin{array}{l}-0.046 \\
(-1.425)\end{array}$ & $\begin{array}{l}-0.007 \\
(-0.568)\end{array}$ & $\begin{array}{l}-0.024 \\
(-1.174)\end{array}$ & $\begin{array}{c}0.016 \\
(1.285)\end{array}$ & $\begin{array}{l}-0.033 \\
(-1.032)\end{array}$ & $\begin{array}{l}-0.014 \\
(-1.220)\end{array}$ & $\begin{array}{l}0.007 \\
(0.419)\end{array}$ \\
\hline INNOVATION $_{j, i, t}$ & $\begin{array}{l}0.878^{\star \star \star} \\
(39.938)\end{array}$ & $\begin{array}{l}0.726^{\star \star \star} \\
(17.076)\end{array}$ & $\begin{array}{l}0.880^{\star \star \star} \\
(44.613)\end{array}$ & $\begin{array}{l}0.829^{\star \star \star} \\
(22.170)\end{array}$ & $\begin{array}{l}0.858^{\star \star \star} \\
(30.993)\end{array}$ & $\begin{array}{l}0.650^{\star \star \star} \\
(12.988)\end{array}$ & $\begin{array}{l}0.869^{\star \star \star} \\
(36.200)\end{array}$ & $\begin{array}{l}0.877^{\star \star \star} \\
(25.804)\end{array}$ \\
\hline $\begin{array}{l}\text { No. of obs. } \\
R^{2}\end{array}$ & $\begin{array}{l}8,920 \\
0.778\end{array}$ & $\begin{array}{l}8,920 \\
0.503\end{array}$ & $\begin{array}{l}8,920 \\
0.819\end{array}$ & $\begin{array}{l}8,920 \\
0.671\end{array}$ & $\begin{array}{l}8,920 \\
0.736\end{array}$ & $\begin{array}{l}6,477 \\
0.413\end{array}$ & $\begin{array}{l}8,920 \\
0.763\end{array}$ & $\begin{array}{l}8,920 \\
0.692\end{array}$ \\
\hline $\begin{array}{l}\text { Country-industry FEs } \\
\text { Year FEs }\end{array}$ & $\begin{array}{l}\text { Yes } \\
\text { Yes }\end{array}$ & $\begin{array}{l}\text { Yes } \\
\text { Yes }\end{array}$ & $\begin{array}{l}\text { Yes } \\
\text { Yes }\end{array}$ & $\begin{array}{l}\text { Yes } \\
\text { Yes }\end{array}$ & $\begin{array}{l}\text { Yes } \\
\text { Yes }\end{array}$ & $\begin{array}{l}\text { Yes } \\
\text { Yes }\end{array}$ & $\begin{array}{l}\text { Yes } \\
\text { Yes }\end{array}$ & $\begin{array}{l}\text { Yes } \\
\text { Yes }\end{array}$ \\
\hline \multicolumn{9}{|c|}{ Panel B. The Low Subsample in the Herfindahl Index } \\
\hline ELECTION $_{i, t}$ & $\begin{array}{l}-0.044^{* *} \\
(-2.454)\end{array}$ & $\begin{array}{l}-0.094^{\star \star} \\
(-2.151)\end{array}$ & $\begin{array}{l}-0.045^{* \star *} \\
(-3.181)\end{array}$ & $\begin{array}{l}-0.031^{*} \\
(-1.907)\end{array}$ & $\begin{array}{l}-0.023 \\
(-1.269)\end{array}$ & $\begin{array}{l}-0.035 \\
(-0.846)\end{array}$ & $\begin{array}{l}-0.034^{* *} \\
(-1.985)\end{array}$ & $\begin{array}{l}-0.032 \\
(-1.595)\end{array}$ \\
\hline INNOVATION ${ }_{j, i, t}$ & $\begin{array}{l}0.831^{\star \star \star \star} \\
(21.148)\end{array}$ & $\begin{array}{l}0.556^{\star \star \star} \\
(8.216)\end{array}$ & $\begin{array}{l}0.841^{\star \star \star *} \\
(37.019)\end{array}$ & $\begin{array}{l}0.752^{\star \star \star} \\
(12.640)\end{array}$ & $\begin{array}{l}0.794^{\star \star \star *} \\
(18.451)\end{array}$ & $\begin{array}{l}0.541^{\star \star \star} \\
(8.616)\end{array}$ & $\begin{array}{l}0.816^{\star \star \star} \\
(19.413)\end{array}$ & $\begin{array}{l}0.860^{\star \star \star} \\
(15.794)\end{array}$ \\
\hline $\begin{array}{l}\text { No. of obs. } \\
R^{2}\end{array}$ & $\begin{array}{l}5,940 \\
0.656\end{array}$ & $\begin{array}{l}5,940 \\
0.291\end{array}$ & $\begin{array}{l}5,940 \\
0.73\end{array}$ & $\begin{array}{l}5,940 \\
0.522\end{array}$ & $\begin{array}{l}5,940 \\
0.614\end{array}$ & $\begin{array}{l}4,112 \\
0.283\end{array}$ & $\begin{array}{l}5,940 \\
0.634\end{array}$ & $\begin{array}{l}5,940 \\
0.634\end{array}$ \\
\hline $\begin{array}{l}\text { Country-industry FEs } \\
\text { Year FEs }\end{array}$ & $\begin{array}{l}\text { Yes } \\
\text { Yes }\end{array}$ & $\begin{array}{l}\text { Yes } \\
\text { Yes }\end{array}$ & $\begin{array}{l}\text { Yes } \\
\text { Yes }\end{array}$ & $\begin{array}{l}\text { Yes } \\
\text { Yes }\end{array}$ & $\begin{array}{l}\text { Yes } \\
\text { Yes }\end{array}$ & $\begin{array}{l}\text { Yes } \\
\text { Yes }\end{array}$ & $\begin{array}{l}\text { Yes } \\
\text { Yes }\end{array}$ & $\begin{array}{l}\text { Yes } \\
\text { Yes }\end{array}$ \\
\hline
\end{tabular}

where the dependent variable INVENTOR $_{j, i, t+1}$ denotes the number of patent inventors who have filed at least 1 patent in industry $j$ in country $i$ in year $t+1$. As defined earlier, ELECTION ${ }_{i, t}$ and POLICY PLt $_{i, t}$ capture policy uncertainty and policy, respectively. Other variable definitions remain the same as before.

In Table 6, we find that inventors' incentive to innovate in an economy is severely affected by policy uncertainty. As shown in all columns, the coefficient estimate of ELECTION ${ }_{i, t}$ is negative and significant, suggesting that individuals' incentives to invent significantly decline on average 1 year after national elections. With respect to policy, we do find that the policies of the right suppress the number of inventors filing patents, but we also find that the policies of the right do not affect the total number of patents being filed; rather, they affect citation and originality (in untabulated results). Overall, the identification of this mechanism (inventors' incentive to innovate) to explain why policy uncertainty is negatively linked to innovation lends further support a causal interpretation of our main results. 


\section{TABLE 6}

Regression Analysis for the Relation between Policy, Policy Uncertainty, and Incentive to Innovate

\begin{tabular}{|c|c|c|c|c|}
\hline \multirow[b]{2}{*}{ Variables } & \multicolumn{4}{|c|}{ Inventors } \\
\hline & 1 & 2 & 3 & 4 \\
\hline ELECTION $_{i, t}$ & $\begin{array}{l}-0.020^{\star} \\
(-1.855)\end{array}$ & $\begin{array}{c}-0.020^{\star} \\
(-1.922)\end{array}$ & $\begin{array}{c}-0.020^{\star} \\
(-1.919)\end{array}$ & $\begin{array}{c}-0.020^{\star} \\
(-1.916)\end{array}$ \\
\hline INVENTOR $_{j, i, t}$ & $\begin{array}{l}0.907^{\star \star \star} \\
(14.629)\end{array}$ & $\begin{array}{c}0.907^{\star \star \star} \\
(14.704)\end{array}$ & $\begin{array}{c}0.905^{\star \star \star} \\
(14.684)\end{array}$ & $\begin{array}{l}0.906^{\star \star \star} \\
(14.755)\end{array}$ \\
\hline $\mathrm{GDP}_{i, t}$ & & $\begin{array}{c}0.004 \\
(1.612)\end{array}$ & $\begin{array}{c}0.004 \\
(1.595)\end{array}$ & $\begin{array}{c}0.003 \\
(1.584)\end{array}$ \\
\hline $\mathrm{RIGHT}_{i, t}$ & & & $\begin{array}{l}-0.022^{\star \star} \\
(-2.130)\end{array}$ & \\
\hline $\operatorname{LEFT}_{i, t}$ & & & & $\begin{array}{c}0.017 \\
(1.477)\end{array}$ \\
\hline $\begin{array}{l}\text { No. of obs. } \\
R^{2}\end{array}$ & $\begin{array}{r}24,360 \\
0.659\end{array}$ & $\begin{array}{r}24,360 \\
0.659\end{array}$ & $\begin{array}{r}24,360 \\
0.660\end{array}$ & $\begin{array}{r}24,360 \\
0.660\end{array}$ \\
\hline $\begin{array}{l}\text { Country-industry FEs } \\
\text { Year FEs }\end{array}$ & $\begin{array}{l}\text { Yes } \\
\text { Yes }\end{array}$ & $\begin{array}{l}\text { Yes } \\
\text { Yes }\end{array}$ & $\begin{array}{l}\text { Yes } \\
\text { Yes }\end{array}$ & $\begin{array}{l}\text { Yes } \\
\text { Yes }\end{array}$ \\
\hline
\end{tabular}

\section{F. Policy Uncertainty and Innovation for Different Industries}

If policy uncertainty does adversely affect innovation, this effect should be more pronounced in innovation-intensive industries. To test for this, we estimate the following equation:

$$
\begin{aligned}
& \text { INNOVATION }_{j, i, t+1}=\alpha+\beta_{1} \text { INNOVATION_INTENSITY }_{i, i, t} \times \text { ELECTION }_{i, t} \\
& \quad+\beta_{2} \text { INNOVATION_INTENSITY }_{i, t}+\beta_{3} \text { INNOVATION }_{j, i, t} \\
& \quad+\gamma_{j, i} \text { COUNTRY_INDUSTRY }_{j, i}+\rho_{i, t} \text { COUNTRY_YEAR }_{i, t}+e_{j, i, t} .
\end{aligned}
$$

Here, we follow Acharya and Subramanian (2009) and define INNOVATION_ INTENSITY $_{j, i, t}$ as an industry's propensity to innovate. This indicator variable equals 1 if the innovation measure of industry $j$ is ranked in the top $30 \%$ in country $i$ in year $t$. The definitions of the other variables remain the same as those used to estimate equation (8). ${ }^{23}$ The fixed effects for COUNTRY_INDUSTRY pair control for all time-invariant determinants of innovation for each industry in each country, whereas the fixed effects for COUNTRY_YEAR pair control for all determinants of innovation for each country in a given year. The variable of interest is the interaction term INNOVATION_INTENSITY ${ }_{i, i, t} \times$ ELECTION $_{i, t}$, which reflects the heterogeneous effects of policy uncertainty on innovation across industries.

\footnotetext{
${ }^{23}$ For brevity's sake, we do not include POLICY and GDP in the subsample regressions. Nevertheless, we obtain consistent results when we include those variables in regressions.
} 
Table 7 provides results from estimating equation (10). The coefficient on the interaction term INNOVATION_INTENSITY ${ }_{i, i, t} \times$ ELECTION $_{i, t}$ is negative and significant in all models except in the 2 tails of the citation distribution (top $25 \%$ and bottom $25 \%$ ), suggesting that the negative effect of policy uncertainty on innovation is more pronounced in more innovation-intensive industries. More important, our results are not subject to any time-varying country-specific factors. Therefore, this test lends further confidence to causality.

\section{G. Other Issues}

For robustness and completeness, we now explore the relation between R\&D and policy and policy uncertainty. Complete country-level R\&D data for developing countries are unavailable until most recently (e.g., Keller (2004)). Even worse, these data are usually unavailable at the industry level; thus, we resort to the Worldscope database, which covers only publicly traded firms and leaves out R\&D efforts that privately held firms and individuals conduct. In addition, the practice of reporting $R \& D$ is sensitive to accounting standards such as whether it should be capitalized or expensed, as argued by Acharya and Subramanian (2009). In fact, many non-U.S. firms do not report or are not required to report $R \& D$ expenses in their financial statements. Finally, R\&D activities may be subject to managerial discretions and associated agency costs due to their accounting treatment (Dechow and Sloan (1991), Lev (1999), and Bereskin, Hsu, and Rotenberg (2016)).

\section{TABLE 7}

Regression Analysis for the Relation between Policy Uncertainty and Innovation in Different Industries

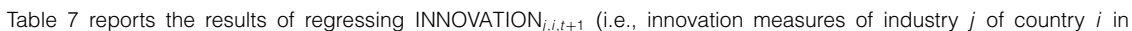
year $t+1$ ) on ELECTION $i, t$ (an indicator variable that equals 1 if there is at least 1 election in country $i$ in year $t$, and 0 otherwise) interacted with INNOVATION_INTENSITY ${ }_{j, i, t}$ (an indicator variable that equals 1 if the innovation measure of industry $j$ is ranked in the top $30 \%$ in country $i$ in year $t$ ), INNOVATION_INTENSITY $j, i$, , country-industry fixed effects (FEs), and country-year FEs. We do not include ELECTION $_{i, t}$ in the regression because it is absorbed by country-year FEs. INNOVATION ${ }_{i, i, t}$ denotes the logarithmic value of 1 plus PATENT PAi,t $_{\text {, CITATION }}$ CI,i,t $_{\text {, }}$ ORIGINALITY $Y_{j, i, t}, \quad$ CITATION_TOP_25_PCT $, i, t, \quad$ CITATION_BOTTOM_25_PCT $, i, t, \quad$ CITATION_STD_DEV, , EXPLORATION $_{j, i, t}$, and EXPLOITATION ${ }_{j, i, t}$. We include all 43 countries in our sample. Numbers reported in parentheses are standard errors clustered by country-industries. The sample year $t$ is from 1976 to 2010 . ${ }^{*},{ }^{\star *}$, and ${ }^{* \star *}$ indicate statistical significance at the $10 \%, 5 \%$, and $1 \%$ levels, respectively.

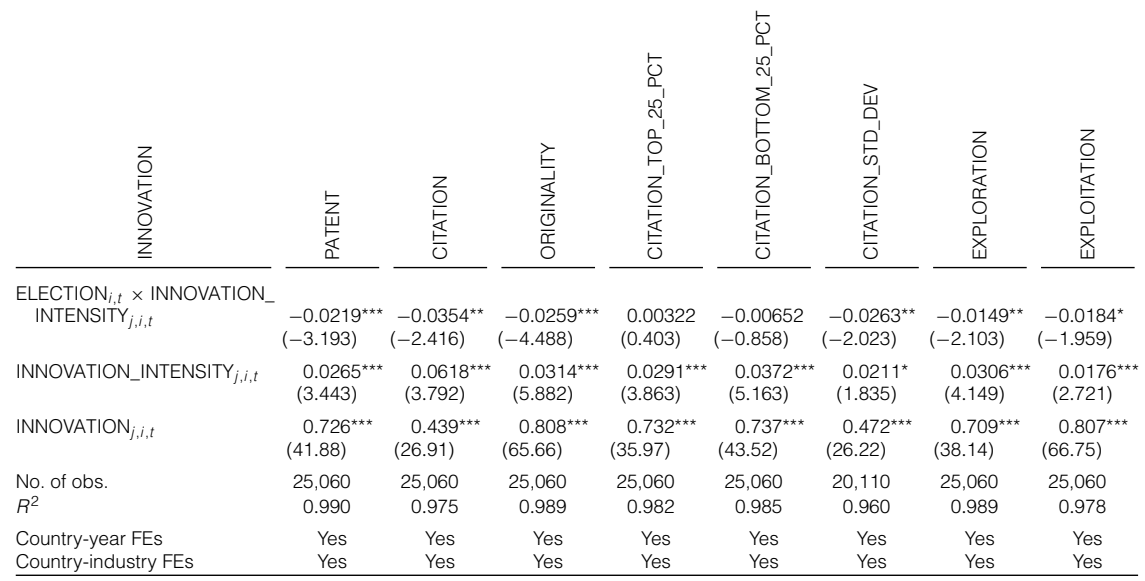


Nevertheless, we estimate

$$
\begin{aligned}
& \mathrm{RD}_{j, i, t+1}=\alpha+\beta_{1} \mathrm{ELECTION}_{i, t}+\beta_{2} \mathrm{POLICY}_{i, t}+\beta_{3} \mathrm{GDP}_{i, t}+\beta_{4} \mathrm{RD}_{j, i, t} \\
& +\gamma_{j, i} \text { COUNTRY INDUSTRY }_{j, i}+\rho_{t} \mathrm{YEAR}_{t}+e_{j, i, t} \text {, }
\end{aligned}
$$

where $\mathrm{RD}_{j, i, t+1}$ is the natural logarithm of total $\mathrm{R} \& \mathrm{D}$ expenses reported by all publicly listed firms in industry $j$ in country $i$ in year $t+1$ in the Worldscope database. The results of this test are reported in Table IA2 in the Internet Appendix. We find that, consistent with our earlier patent-based results, the coefficient on ELECTION is negative and significant, but the coefficient on policy (RIGHT or LEFT) is insignificant.

Until now, we test whether policy uncertainty and policy affect innovation levels and R\&D levels. We now examine whether policy uncertainty and policy also affect innovation growth rates. Tables IA3 and IA4 in the Internet Appendix are parallel to Tables 2 and 3 in the text, respectively, with innovation levels replaced by innovation growth rates. In Table IA3, consistent with earlier level-based results, we find that policy uncertainty adversely affects growth rates of patent filings, total citations, originality, influential patents (top $25 \%$ in citation), and exploratory patents. Table IA4 presents similar, albeit slightly weaker, results. We conclude that policy uncertainty also adversely affects the growth of innovation, whereas policy does not (except in one case).

\section{Conclusion}

In this article we examine whether it is policy or policy uncertainty that affects technological innovation. Motivated by predictions from a theoretical framework, we empirically test whether policy uncertainty affects a country's innovation, whether policy affects a country's innovation, and which of these two affects a country's innovation to a larger degree. We find that policy, on average, does not affect a country's innovation activities. Policy uncertainty, however, adversely affects a country's innovation quantity, quality, and originality. In particular, the drop is greater for more influential innovations (citations in the right tail, exploratory rather than exploitative innovations), and is greater for innovationintensive industries. In addition, policy uncertainty hurts the economy's incentive to innovate, which is a direct channel through which policy uncertainty negatively affects a country's innovation activities. Moreover, the adverse effect of policy uncertainty on innovation is stronger among ethnically heterogeneous countries, and is stronger for more innovative industries.

Our results suggest that businesses adapt to different policies but face a problem when they do not know which policy to adapt to. Our research thus suggests that in terms of motivating innovation in most democracies, it does not matter which policy prevails. What matters is political gridlock and the resultant policy uncertainty, because they have real adverse economic consequences: a reduction in the quantity, quality, originality, and riskiness of innovation activities in a country. Political compromise, therefore, is good for innovation. 


\section{References}

Acharya, V.; R. Baghai; and K. Subramanian. "Labor Laws and Innovation." Journal of Law and Economics, 56 (2013), 997-1037.

Acharya, V.; R. Baghai; and K. Subramanian. "Wrongful Discharge Laws and Innovation." Review of Financial Studies, 27 (2014), 301-346.

Acharya, V., and K. Subramanian. "Bankruptcy Codes and Innovation." Review of Financial Studies, 22 (2009), 4949-4988.

Aghion, P.; N. Bloom; R. Blundell; R. Griffith; and P. Howitt. "Competition and Innovation: An Inverted U Relationship." Quarterly Journal of Economics, 120 (2005), 701-728.

Aghion, P., and J. Tirole. "On the Management of Innovation." Quarterly Journal of Economics, 109 (1994), 1185-1209.

Aghion, P.; J. Van Reenen; and L. Zingales. "Innovation and Institutional Ownership." American Economic Review, 103 (2013), 277-304.

Ahuja, G. "Collaboration Networks, Structural Holes, and Innovation: A Longitudinal Study." Administrative Science Quarterly, 45 (2000), 425-455.

Akey, P. "Valuing Changes in Political Networks: Evidence from Campaign Contributions to Close Congressional Elections." Review of Financial Studies, 28 (2015), 3188-3223.

Alesina, A.; A. Devleeschauwer; W. Easterly; S. Kurlat; and R. Wacziarg. "Fractionalization." Journal of Economic Growth, 8 (2003), 155-194.

Alesina, A., and R. Perotti. "Income Distribution, Political Instability and Investment." European Economic Review, 40 (1996), 1202-1229.

Arora, A., and A. Gambardella. "Complementarity and External Linkages: The Strategies of the Large Firms in Biotechnology." Journal of Industrial Economics, 38 (1990), 361-379.

Baker, S.; N. Bloom; and S. J. Davis. "Measuring Economic Policy Uncertainty." Quarterly Journal of Economics, 131 (2016), 1593-1636.

Balsmeier, B.; L. Fleming; and G. Manso. "Independent Boards and Innovation." Journal of Financial Economics, 123 (2017), 536-557.

Benner, M., and R. Ranganathan. "Offsetting Illegitimacy? How Pressures from Securities Analysts Influence Incumbents in the Face of New Technologies." Academy of Management Journal, 55 (2012), 213-233.

Bereskin, F.; P. H. Hsu; and W. Rotenberg. "The Real Effects of Real Earnings Management: Evidence from Innovation." Working Paper, University of Toronto (2016).

Bernanke, B. "Irreversibility, Uncertainty, and Cyclical Investment." Quarterly Journal of Economics, 98 (1983), 85-106.

Bloom, N.; S. Bond; and J. Van Reenen. "Uncertainty and Investment Dynamics." Review of Economic Studies, 74 (2007), 391-415.

Bloom, N.; M. Draca; and J. Van Reenen. "Trade Induced Technical Change: The Impact of Chinese Imports on Innovation, Diffusion and Productivity.” Review of Economic Studies, 83 (2016), 87-117.

Bloom, N.; M. Schankerman; and J. Van Reenen. "Identifying Technology Spillovers and Product Market Rivalry." Econometrica, 81 (2013), 1347-1393.

Boutchkova, M.; H. Doshi; A. Durnev; and A. Molchanov. "Precarious Politics and Return Volatility." Review of Financial Studies, 25 (2012), 1111-1154.

Brogaard, J.; M. Denes; and R. Duchin. "Political Influence and Government Investment: Evidence from Contract-Level Data." Working Paper, University of Washington (2016).

Brogaard, J., and A. Detzel. "The Asset Pricing Implications of Government Economic Policy Uncertainty." Management Science, 61 (2015), 3-18.

Chava, S.; A. Oettl; A. Subramanian; and K. Subramanian. "Banking Deregulation and Innovation." Journal of Financial Economics, 109 (2013), 759-774.

Chemmanur, T.; E. Loutskina; and X. Tian. "Corporate Venture Capital, Value Creation, and Innovation." Review of Financial Studies, 27 (2014), 2434-2473.

Chen, G.; H. Gao; P. H. Hsu; and K. Li. "Innovation Strategy and Initial Public Offerings." Working Paper, INSEAD (2016).

Chen, Y. F., and M. Funke. "Option Value, Policy Uncertainty, and the Foreign Direct Investment Decision." Hamburg Institute of International Economics Discussion Paper (2003).

Chung, W., and J. Alcácer. "Knowledge Seeking and Location Choice of Foreign Direct Investment in the United States." Management Science, 53 (2002), 760-776.

Connor, W. Ethnonationalism. Princeton, NJ: Princeton University Press (1994).

Cornaggia, J.; Y. Mao; X. Tian; and B. Wolfe. "Does Banking Competition Affect Innovation?" Journal of Financial Economics, 115 (2015), 189-209. 
Dechow, P., and R. Sloan. "Executive Incentives and the Horizon Problem: An Empirical Investigation." Journal of Accounting and Economics, 14 (1991), 51-89.

Derrien, F., and A. Kecskés. "The Real Effects of Financial Shocks: Evidence from Exogenous Changes in Analyst Coverage." Journal of Finance, 68 (2013), 1383-1416.

Durnev, A. "The Real Effects of Policy Uncertainty: Elections and Investment Sensitivity to Stock Prices." Working Paper, University of Iowa (2011).

Dutta, S., and B. Lanvin. The Global Innovation Index 2013: The Local Dynamics of Innovation. Geneva, Ithaca, and Fontainebleau: Cornell University, INSEAD, and the World Intellectual Property Organization (2013).

Easterly, W., and R. Levine. "Africa's Growth Tragedy: Policies and Ethnic Divisions." Quarterly Journal of Economics, 111 (1997), 1203-1250.

Edmans, A. "Blockholder Trading, Market Efficiency, and Managerial Myopia." Journal of Finance, 64 (2009), 2481-2513.

Ellison, G., and E. L. Glaeser. "Geographic Concentration in U.S. Manufacturing Industries: A Dartboard Approach.” Journal of Political Economy, 105 (1997), 889-927.

Fang, V.; X. Tian; and S. Tice. "Does Stock Liquidity Enhance or Impede Firm Innovation?” Journal of Finance, 69 (2014), 2085-2125.

Ferreira, D.; G. Manso; and A. Silva. "Incentives to Innovate and the Decision to Go Public or Private." Review of Financial Studies, 27 (2014), 256-300.

Griffith, R.; R. Harrison; and J. Van Reenen. "How Special Is the Special Relationship? Using the Impact of U.S. R\&D Spillovers on U.K. Firms as a Test of Technology Sourcing." American Economic Review, 96 (2006), 1859-1875.

Griliches, Z.; A. Pakes; and B. Hall. "The Value of Patents as Indicators of Inventive Activity." NBER Working Paper 2083 (1988).

Gulen, H., and M. Ion. "Policy Uncertainty and Corporate Investment." Review of Financial Studies, 29 (2016), 523-564.

Hall, B.; Z. Griliches; and J. Hausman. "Patents and R\&D: Is There a Lag?" International Economic Review, 27 (1986), 265-283.

Hall, B.; A. Jaffe; and M. Trajtenberg. "The NBER Patent Citation Data File: Lessons, Insights and Methodological Tools.” NBER Working Paper 8498 (2001).

Hall, B.; A. Jaffe; and M. Trajtenberg. "Market Value and Patent Citations." RAND Journal of Economics, 36 (2005), 16-38.

Harhoff, D.; F. Narin; F. M. Scherer; and K. Vopel. "Citation Frequency and the Value of Patented Inventions." Review of Economics and Statistics, 81 (1999), 511-515.

Hausman, J.; B. Hall; and Z. Griliches. "Econometric Models for Count Data with an Application to the Patents-R\&D Relationship." Econometrica, 52 (1984), 909-938.

He, J., and X. Tian. "The Dark Side of Analyst Coverage: The Case of Innovation." Journal of Financial Economics, 109 (2013), 856-878.

Heckelman, J., and H. Berument. "Political Business Cycles and Endogenous Elections." Southern Economic Journal, 64 (1998), 987-1000.

Henisz, W. "The Institutional Environment for Economic Growth.” Economics and Politics, 12 (2000), $1-31$.

Hirshleifer, D.; P. H. Hsu; and D. Li. "Innovative Efficiency and Stock Returns.” Journal of Financial Economics, 107 (2013), 632-654.

Hirshleifer, D.; P. H. Hsu; and D. Li. "Innovative Originality, Profitability, and Stock Returns." Review of Financial Studies, forthcoming (2017).

Holmstrom, B. “Agency Costs and Innovation.” Journal of Economic Behavior and Organization, 12 (1989), 305-327.

Hsu, P. H. "Technological Innovations and Aggregate Risk Premiums.” Journal of Financial Economics, 94 (2009), 264-279.

Hsu, P. H.; X. Tian; and Y. Xu. "Financial Market Development and Innovation: Cross-Country Evidence." Journal of Financial Economics, 112 (2014), 116-135.

Jaffe, A., and M. Trajtenberg. Patents, Citations, and Innovations. Cambridge, MA: MIT Press (2002).

Julio, B., and Y. Yook. "Policy Uncertainty and Corporate Investment Cycles." Journal of Finance, 67 (2012), 45-83.

Julio, B., and Y. Yook. "Policy Uncertainty, Irreversibility, and Cross-Border Flows of Capital." Journal of International Economics, 103 (2016), 13-26.

Keefer, P. Database of Policies Institutions: Changes and Variable Definitions. Washington, DC: The World Bank (2010).

Keefer, P., and S. Knack. "Polarization, Politics and Property Rights: Links between Inequality and Growth." Public Choice, 111 (2002), 127-154.

Keller, W. "International Technology Diffusion.” Journal of Economic Literature, 42 (2004), 752-782. 
Kelly, B.; L. Pastor; and P. Veronesi. "The Price of Political Uncertainty: Theory and Evidence from the Option Market." Working Paper, University of Chicago (2014).

Knack, S., and P. Keefer. "Does Social Capital Have an Economic Payoff? A Cross-Country Investigation." Quarterly Journal of Economics, 112 (1997), 1251-1288.

Kogan, L.; D. Papanikolaou; A. Seru; and N. Stoffman. "Technological Innovation, Resource Allocation, and Growth." Quarterly Journal of Economics, 132 (2017), 665-712.

La Porta, R.; F. Lopez-de-Silanes; A. Shleifer; and R. Vishny. "The Quality of Government." Journal of Law, Economics, and Organization, 15 (1999), 222-279.

Lerner, J. "The Empirical Impact of Intellectual Property Rights on Innovation: Puzzles and Clues." American Economic Review, Papers and Proceedings, 99 (2009), 343-348.

Lerner, J.; M. Sorensen; and P. Stromberg. "Private Equity and Long-Run Investment: The Case of Innovation." Journal of Finance, 66 (2011), 445-477.

Lerner, J., and A. Seru. "The Use and Misuse of Patent Data: Issues for Corporate Finance and Beyond." Working Paper, Harvard University and University of Chicago (2015).

Lerner, J., and J. Wulf. "Innovation and Incentives: Evidence from Corporate R\&D." Review of Economics and Statistics, 89 (2007), 634-644.

Lev, B. "R\&D and Capital Markets." Journal of Applied Corporate Finance, 11 (1999), 21-35.

Li, G. C.; R. Lai; A. D’Amour; D. M. Doolin; Y. Sun; V. I. Torvik; A. Z. Yu; and L. Fleming. "Disambiguation and Co-Authorship Networks of the U.S. Patent Inventor Database (1975-2010)." Research Policy, 43 (2014), 941-955.

Manso, G. "Motivating Innovation." Journal of Finance, 66 (2011), 1823-1860.

Nanda, R., and M. Rhodes-Kropf. "Investment Cycles and Startup Innovation." Journal of Financial Economics, 110 (2013), 403-419.

Pastor, L., and P. Veronesi. "Uncertainty about Government Policy and Stock Prices." Journal of Finance, 64 (2012), 1219-1264.

Pastor, L., and P. Veronesi. "Political Uncertainty and Risk Premia." Journal of Financial Economics, 110 (2013), 520-545.

Radro i Miquel, G. "The Control of Politicians in Divided Societies: The Politics of Fear." Review of Economic Studies, 74 (2007), 1259-1274.

Rosenberg, N. "Innovation and Economic Growth." OECD (2004), 1-6.

Sapra, H.; A. Subramanian; and K. Subramanian. "Corporate Governance and Innovation: Theory and Evidence.” Journal of Financial and Quantitative Analysis, 49 (2014), 957-1003.

Seru, A. "Firm Boundaries Matter: Evidence from Conglomerates and R\&D Activity." Journal of Financial Economics, 111 (2014), 381-405.

Snowberg, E.; J. Wolfers; and E. Zitzewitz. "Partisan Impacts on the Economy: Evidence from Prediction Markets and Close Elections." Quarterly Journal of Economics, 122 (2007), 807-829.

Solow, R. "Technical Change and the Aggregate Production Function." Review of Economics and Statistics, 39 (1957), 312-320.

Stein, J. “Takeover Threats and Managerial Myopia." Journal of Political Economy, 96 (1988), 61-80.

Tian, X., and T. Wang. "Tolerance for Failure and Corporate Innovation." Review of Financial Studies, 27 (2014), 211-255.

Trajtenberg, M. "A Penny for Your Quotes: Patent Citations and the Value of Innovations." RAND Journal of Economics, 21 (1990), 172-187.

Zingales, L. "In Search of New Foundations." Journal of Finance, 55 (2000), 1623-1653. 